IZA DP No. 5803

Does Early Life Health Predict Schooling Within Twin Pairs?

Petter Lundborg

Anton Nilsson

Dan-Olof Rooth

June 2011 


\title{
Does Early Life Health Predict Schooling Within Twin Pairs?
}

\author{
Petter Lundborg \\ Lund University, VU University Amsterdam, \\ Tinbergen Institute, Netspar, HEP and IZA \\ Anton Nilsson \\ Lund University \\ Dan-Olof Rooth \\ Linnaeus University, \\ Lund University, CReAM and IZA
}
Discussion Paper No. 5803
June 2011

\author{
IZA \\ P.O. Box 7240 \\ 53072 Bonn \\ Germany \\ Phone: +49-228-3894-0 \\ Fax: +49-228-3894-180 \\ E-mail: iza@iza.org
}

Any opinions expressed here are those of the author(s) and not those of IZA. Research published in this series may include views on policy, but the institute itself takes no institutional policy positions.

The Institute for the Study of Labor (IZA) in Bonn is a local and virtual international research center and a place of communication between science, politics and business. IZA is an independent nonprofit organization supported by Deutsche Post Foundation. The center is associated with the University of Bonn and offers a stimulating research environment through its international network, workshops and conferences, data service, project support, research visits and doctoral program. IZA engages in (i) original and internationally competitive research in all fields of labor economics, (ii) development of policy concepts, and (iii) dissemination of research results and concepts to the interested public.

IZA Discussion Papers often represent preliminary work and are circulated to encourage discussion. Citation of such a paper should account for its provisional character. A revised version may be available directly from the author. 
IZA Discussion Paper No. 5803

June 2011

\title{
ABSTRACT
}

\section{Does Early Life Health Predict Schooling Within Twin Pairs?}

\begin{abstract}
A large number of studies in labor economics estimate the returns to schooling using data on monozygotic twins, under the assumption that educational attainment is random within twin pairs. This exogeneity assumption has been commonly questioned, however, but there is to date little evidence on the topic. Using a large dataset of twins, including comprehensive information on their health status at the age of 18 and later educational attainment, we investigate whether educational attainment is related to early health status within monozygotic twin pairs. In general, we obtain no indication of this being so. As a result, we find little evidence that early health differences between twins would bias the estimates of the returns to schooling available in the literature.
\end{abstract}

JEL Classification: $\quad$ I1, I2

Keywords: twins, twin-fixed effects, schooling, returns to schooling, ability bias, health

Corresponding author:

Dan-Olof Rooth

Linnaeus School of Business and Economics

Linnaeus University

Kalmar Nyckel

SE-39182 Kalmar

Sweden

E-mail: Dan-Olof.Rooth@Inu.se 


\section{Introduction}

The returns to schooling is one of the most studied issues in labor economics (see Card, 1999, for an overview). At the same time, obtaining a causal estimate of the returns to schooling is one of the most challenging tasks facing applied researchers and there is no real consensus as to what constitutes the "gold standard". First of all, there has always been a concern that standard OLS regression estimates suffer from endogeneity bias as schooling is not likely to be random but instead related to (typically unobserved) personal characteristics, which also independently affect wage earning capability. Such factors are usually referred to as ability, but most likely include a much broader range of personal characteristics than just ability in the sense of "intelligence".

One of the main approaches that have been used to deal with this possible endogeneity problem is to use monzygotic (MZ) twins (e.g. Ashenfelter and Krueger, 1994; Isacsson, 2004). Applying a twin fixed effects estimator, an unbiased estimate of the returns to schooling can be obtained under the assumption that twins have equal abilities, so that schooling is exogenous at the twin-pair level.

Despite its popularity, it is unclear whether this approach is reasonable. While MZ twins indeed share the same genes and family environment, they may very well differ in respects that are related to their schooling investment decision. Consequently, studies in this literature may have produced biased results as such factors have not been controlled for. This criticism was for instance formulated by Bound and Solon (1999), who argued that endogeneity bias may even increase using the twin design, if the method "differences out" more exogenous variation than endogenous variation. Very few studies have investigated the exogeneity assumption in a systematic manner, however. This likely reflects that few datasets of twins include measures such as cognitive ability, or health status - which one may view as just another aspect of ability - 
early in life. ${ }^{1}$

Our study makes a contribution to the small literature investigating the exogeneity assumption by examining whether there is a systematic relationship between various measures of early health status and later educational attainment within monozygotic twin pairs. If such a relationship is obtained, it would suggest that conventional estimates of the returns to schooling using the twin approach may partly reflect the returns to health rather than to schooling. While a few studies have previously investigated the influence of a single measure of early health, such as birth weight, using MZ twins, we are aware of no previous study that uses data on a large set of health outcomes and relate these various outcomes to later educational attainment.

We use a unique dataset including a large majority of all native Swedish male twins born between 1950 and 1979. Our dataset links information on health status at the age of 18 from military enlistment records to administrative records on educational attainment, and also includes information on zygosity for most individuals, allowing us to separate out MZ twins. In addition, our data allows us to control for cognitive ability (roughly the same as IQ) as well as a measure of noncognitive ability (reflecting character traits such as emotional stability and persistence).

In contrast to most twin-based studies in economics, we have access to data on objective early life health conditions. These are reported by physicians based on obligatory assessments of the individuals' health. While these assessments must inevitably to some extent rely on selfreports, measurement errors for example originating from differences in health-seeking behaviors or in health awareness, which may be present in sources like hospital and insurance records or standard self-evaluations, are less of an issue. This is potentially important in light of the

\footnotetext{
${ }^{1}$ Using measures of health later in life is more problematic because these may themselves be outcomes of earnings and educational level.
} 
criticism of Bound and Solon (1999) and others, that fixed effects estimation exacerbates measurement errors.

The health measures available in the dataset reflect a broad range of aspects of health. Not only are specific (physical and mental) health conditions included, but the health status of each individual has also been transformed into a unidimensional measure of global health. In addition, a large number of "physical test variables" are available, including for example handgrip strength, height, physical capacity and blood pressure.

We first run OLS regressions, in order to obtain some "baseline" results. In agreement with many previous studies, we then find a number of significant relationships between health status and educational attainment. When applying fixed effects estimators, our results in general point to the absence of a health-education relationship, as coefficients approach zero and become insignificant. As a consequence, our study provides little evidence that estimates obtained in twin-based studies of the returns to schooling using MZ twins may be biased by unobserved health differences between the twins.

The rest of the paper is organized as follows. Section 2 provides a background discussion and reviews some relevant literature. In section 3 we present the empirical model, describe the data material, the construction of variables, and the sample restrictions. Section 4 presents the results, whereas section 5 provides a concluding discussion.

\section{Background}

In the literature estimating the returns to education, two main approaches have been taken to deal with the potential endogeneity of schooling. The first approach is to make use of institutional features of, or changes in, the schooling system (see e.g. Angrist and Krueger, 1991; Maluccio, 
1998; Oreopoulos, 2006; Pischke and von Wachter, 2008) and apply an instrumental variables or regression discontinuity technique. For example, the well-known study by Angrist and Krueger (1991) exploits the fact that children in the US start school at a particular time of the year irrespective of their month of birth, but are in general allowed to drop out of school outright on their 16th or 17th birthday. As a result, month of birth can be used to instrument schooling. Other studies, such as Oreopoulos (2006) and Pischke and von Wachter (2008) exploit changes in mandatory schooling laws to isolate exogenous variation in the years of schooling.

A well known potential problem with all these studies is however that the instruments only affect a limited subsample of the study population. Under certain assumptions, the resulting IV estimate will then reflect a Local Average Treatment Effect (LATE) for the affected population. This population may or may not be the one of interest for policy-makers.

The second main approach has been to use family information in order to control for ability. For example, Ashenfelter and Zimmerman (1997) use information on brother's or father's education. However, in order to more fully control for environmental influences as well as genetic factors, a growing number of studies have used twins, and in particular monozygotic twins (e.g. Ashenfelter and Krueger, 1994; Bonjour et al. 2003; Isacsson, 2004; Miller et al., 1995). The occurrence of a monozygotic twin birth is a more or less random event from the parent's perspective, and so results from these studies can be argued to be quite representative for larger populations.

Applying a fixed effects estimator, the returns to schooling is identified under the assumption that the two individuals within the same twin pair share more or less the same ability. Under this assumption, the twin estimator will normally also provide an Average Treatment 
Effect (ATE) for the twin population under study. ${ }^{2}$ To be specific, relationships of the following form are assumed:

$$
W_{i j}=\alpha+\beta S_{i j}+\gamma Z_{i j}+\delta A_{i}+\varepsilon_{i j}
$$

where $i$ represents the twin pair and $j=1,2$ represents the individual twin; 1 and 2 are assigned randomly. $W$ is log wage, $S$ is schooling, and $A$ is a scalar or vector representing (unobserved) ability. Some authors also include a vector of individual-specific controls, which we denote by $Z$. For example, Ashenfelter and Krueger (1994) include controls for union status, job tenure and marital status.

Letting $j=1$ and 2 , and then taking the difference gives the following expression:

$$
W_{i 1}-W_{i 2}=\beta\left(S_{i 1}-S_{i 2}\right)+\gamma\left(Z_{i 1}-Z_{i 2}\right)+\varepsilon_{i 1}-\varepsilon_{i 2}
$$

where ability obviously plays no role. Estimating this equation using OLS produces the "twinfixed effects" estimator of the returns to schooling, $\beta$.

On the other hand, ability may differ between twins. If this is the case, the true relationship would instead be given by:

$$
W_{i j}=\alpha+\beta S_{i j}+\gamma Z_{i j}+\delta A_{i j}+\varepsilon_{i j}
$$

and twin differencing would not eliminate ability:

\footnotetext{
${ }^{2}$ Given that within-twins differences in schooling are equally common among all subgroups of the twin population.
} 


$$
W_{i 1}-W_{i 2}=\beta\left(S_{i 1}-S_{i 2}\right)+\gamma\left(Z_{i 1}-Z_{i 2}\right)+\delta\left(A_{i 1}-A_{i 2}\right)+\varepsilon_{i 1}-\varepsilon_{i 2} .
$$

Estimating equation (2.2) when the true relationship is given by (2.3) gives rise to an omitted variables bias, as shown by equation (2.5):

$$
E[b]=\beta+\left(\Delta X^{\prime} \Delta X\right)^{-1}{ }_{1} \Delta X^{\prime} \Delta A \delta=\beta+\eta_{A S} \delta,
$$

where within-twins differences in schooling and in control variables have been collected in the matrix $\Delta X$, and within-twins differences in ability have been collected in the vector or matrix $\Delta A$. The subscript on $\left(\Delta X^{\prime} \Delta X\right)^{-1}$ refers to the first row of this matrix. $\eta_{A S}$ is the regression coefficients on $\Delta S$ from OLS regressions of (the components of) $\Delta A$ on $\Delta S$ and $\Delta Z$. It follows that the estimate of $\beta$ will be biased in the presence of within-twins differences in ability given that these are correlated with within-twins differences in educational attainment, conditional on the controls included. ${ }^{3}$

\footnotetext{
${ }^{3}$ What matters is the presence of a correlation between ability and educational attainment within twin pairs, but the mechanisms behind this correlation (or non-correlation) are not important. For example, Tancredy and Fraley (2006) document evidence on the attachment and proximity seeking behavior between twins. As a result of this, while health may have direct effects on educational attainment, these effects may well be counteracted as twins can be expected to influence each other in their schooling decisions. Consequently, no or only a weak correlation between health and educational attainment would be obtained within twin pairs. Similarly, the direct effect of health on schooling may be reinforced or compensated by parental treatment of the twins. This is neither important from our perspective as long as parental behaviors are not both independently related to within-twin pair differences in schooling, and within-twin pair differences in future earnings, in which case another bias of the returns to schooling would be induced.
} 
The possibility that MZ twins differ in ability has always been known (see Card, 1999). Surprisingly few studies have attempted to investigate this claim, however. In their study, Ashenfelter and Rouse (1998) asked MZ twins differing in educational attainment for reasons why one twin had obtained more schooling than the other. Only $11 \%$ of the responses included explanations such as "one twin was better at books", leading the authors to conclude that ability differences between twins was not an important issue. Moreover, the authors show that parents of twins tend to select names that are very similar in sound and/or writing, suggesting that parents try to treat twin children identically.

Using the Swedish Twin Registry, Isacsson (1999) considers whether various psychological measures, including the degree of psychological instability, predict schooling differences between MZ twins. He finds no evidence suggesting so. Lundborg (2010), on the other hand, finds that variation in retrospective measures of early parental treatment predicts schooling differences between MZ twins in the US. His results suggest that differences in parental investments are negatively associated with schooling within twin pairs. He interprets this finding as evidence that parents try to compensate for ability differences between their twins.

In another study using Swedish data, Sandewall et al. (2009) investigate whether differences in cognitive ability test scores between monozygotic twins are related to differences in educational attainment. The authors establish strong evidence that differences in cognitive ability at age 18 positively predicts schooling differences at later ages, which suggests an upward bias in twin-based estimates of the returns to schooling. The authors estimate this bias to amount to about 15 percent.

Regarding health, which is the ability measure of our interest, a number of studies have considered the influence of birth weight on schooling differences within twin pairs. The results 
are rather mixed. Studies such as Behrman and Rosenzweig (2004), Black et al. (2007) and Royer (2009) have found evidence of a negative effect of low birth weight on schooling as well as earnings. It should be noted that the estimated effect of birth weight on educational attainment is in general very small, however. Royer (2009), for instance, finds that a 250 grams increase in birth weight, which would be a substantial policy achievement, is associated with only 0.03-0.04 more years of schooling. Moreover, since Royer (2009) is not able to distinguish between MZ and DZ twins, this result could in principle be explained by unobserved differences in genes within DZ twin pairs and would thus not hold within MZ twin pairs.

Other studies examining whether there is a relationship between birth weight and schooling within twin pairs, such as Miller et al. (2005), Bonjour et al. (2003) and Oreopoulos (2006), find no effect. These differences in results may for instance reflect differences across contexts in the willingness of parents to compensate for (or reinforce) differences in birth weight between the twins.

Studies using measures of early life health other than birth weight and such indicators of health already around birth have in general not had access to data on twins. For example, Smith (2009) and Currie et al. (2010) instead make use of siblings. Smith (2009) uses data from the Panel Study of Income Dynamics, where the health measure available is based on retrospective self-reports of global health status in childhood. Interestingly, while poor childhood health was found to have large effects on outcomes such as adult earnings and wealth, no evidence of a relationship between childhood health and educational attainment was obtained. Currie et al. (2010), on the other hand, using data from public health insurance records with information on particular health diagnoses, establish a number of important relationships between early health and schooling attainment within siblings, particularly for mental conditions. Whether these 
relationships would also have been found within monozygotic twins is, of course, not quite possible to know from their analysis.

\section{Data and method}

\subsection{Data}

Our dataset links data on native Swedish males born 1950-1979 from surveys run by the Swedish Twin Registry to data on educational attainment from Statistics Sweden (Statistiska centralbyrån) from 2007, and to data from tests and medical examinations performed at military enlistment 1969-1997, as provided by the Swedish National Service Administration (Pliktverket). For all these years, young Swedish males were obliged by law to undergo the military enlistment procedure, with exemptions only granted for individuals with severe physical or mental handicaps, prisoners, and individuals living abroad. Individuals usually took the test at the age of 18. The military enlistment records include up to six medical conditions for every individual, using the ICD-8 and ICD-9 classifications (WHO, 1967; WHO, 1977; WHO, 1978). ${ }^{4}$ There is also a global health measure available, which is based on the severeness of the individual's health conditions (both physical and mental) and is used to determine his suitability with respect to type of military service.

Zygosity has been determined for $85 \%$ of the individuals in our dataset, based on survey questions regarding co-twin similarity. The method used has been found to classify twins with an accuracy of $95 \%$ or more (see Lichtenstein, 2002). In total, 4,868 individuals that are (classified as) monozygotic are available in our data.

\footnotetext{
${ }^{4}$ Starting in 1989, diseases were reported using the ICD-9 classification. For individuals whose health conditions are reported using ICD-9, a maximum of two rather than six conditions per person are available in our data.
} 
Educational attainment is expressed in terms of the highest degree attained, as of 2007. There is also information on parents' educational attainment, as of 1999. Our measure of years of schooling is assigned based on the standard number of years of schooling associated with this degree.

We make use of a number of physical test variables that proxy certain aspects of an individual's health. These include measures of handgrip strength (strength of strongest hand when squeezing a dynamometer), physical capacity (as measured by the maximum number of watts attained when riding on a stationary bike), visual acuity (based the ability to see letters on different lines on an eye chart), hearing acuity (the lowest number of decibels the individual was able to hear at 500, 1000, 2000, 3000, 4000 and 6000 hertz), blood pressure, height, and body mass. ${ }^{5}$ However, as we want these variables to be indicators of bad health, we transform these into binary indicators. More specifically, we classify individuals as having weak handgrip strength, low physical capacity, low visual acuity or being short if they fall below the 5th percentiles for these measures respectively. ${ }^{6}$ Furthermore, we create an indicator of low hearing acuity which takes the value of one if the individual was unable to hear tones at $30 \mathrm{~dB}$ at 500 ,

\footnotetext{
${ }^{5}$ In a few cases, these variables equal zero, which is unreasonable given the definitions of these (with the exception of hearing acuity, where zero represents deaf). We treat such observations as missing values.

${ }^{6}$ For height, handgrip strength and physical capacity, this procedure needs no further explanation. For visual acuity, things are somewhat more complicated, as several variables are involved: non-corrected vision of right eye, noncorrected vision of left eye, and in addition for individuals with reduced non-corrected visual acuity, vision of left and vision of right eye when using corrective lenses. We define visual acuity as missing if there is missing information on either non-corrected vision on left or right eye. Somewhat less than $5 \%$ of all individuals with nonmissing data then have a visual acuity of 0.7 or lower (where 1 is "normal vision") on either eye, which we thus take as our definition of "low visual acuity”.
} 
1000, 2000, 3000, 4000, or $6000 \mathrm{~Hz}$ with either ear. ${ }^{7}$ Individuals are classified as having hypertension if either their systolic blood pressure is higher than or equal to 140 or their diastolic blood pressure is higher than or equal to 90 , and are classified as being overweight if their BMI is greater than or equal to $25 .{ }^{8}$ With the possible exception of being short, all these indicators presumably reflect what most people would regard as aspects of bad health. However, as a number of studies have reported, childhood disease burden has strong affects on the growth of a person (see Bozzoli et al., 2008, and the references cited there), which motivates our use of being short as an additional indicator of early health status.

We include seven variables for different health conditions, which basically represent the seven most prevalent classes of health conditions given the ICD-8/ICD-9 classifications and our data. ${ }^{9}$ However, because the category of diseases of the respiratory system includes many shortterm and temporary conditions such as common cold, we do not use this category. Instead, we create a category of respiratory conditions including only asthma and hay fever and hypertrophy of tonsils and adenoids. This leaves us with the following health condition variables: mental conditions (including, for example, neurosis and personality disorders), circulatory conditions (e.g. heart conditions), musculoskeletal conditions (e.g. vertebrogenic pain syndrome and scoliosis), conditions of the digestive system (e.g. gastritis and hernia), diseases of the skin and subcutaneous tissue (e.g. eczema), respiratory conditions (only asthma/hay fever/tonsils/ adenoids), and injuries and poisonings. While injuries and poisonings largely consists of short term and temporary conditions, we still consider this category interesting as such outcomes may

\footnotetext{
${ }^{7}$ We define hearing acuity as missing if there is missing information on either left or right ear.

${ }^{8} \mathrm{BMI}$, body mass index, is calculated as (weight in kilograms)/(height in metres) ${ }^{2}$.

${ }^{9}$ With the exception of conditions of the sensory organs as low hearing acuity and low visual acuity are instead studied separately, as discussed above.
} 
reflect important but unobserved behavioral patterns.

The global health measure available in our dataset is expressed with letters from A to M (except "I"), or "U”, "Y", or "Z". The closer to the start of the alphabet the letter assigned to the individual is, the better his general health status is considered to be. "A" thus represents more or less perfect health, which is necessary for "high mobility positions" (e.g. jäger and pilot) and has been assigned to about two-thirds of all individuals for which there is non-missing data. For combat positions, individuals must have been assigned at least a "D"; individuals with a "G" or lower are only allowed to function in "shielded positions" (e.g. meteorology and shoe repairing). Individuals assigned a "Y" or "Z" (in total $8 \%$ ) are not allowed to undergo education within the military. ${ }^{10}$ "U" (0.05 \%) indicates that global health status has not been determined, and we treat this as missing. The global health measure to be used in our analysis is created by transforming "A" into 0 , "B" into 1 etc., "Y" into 12 and "Z" into $13 .{ }^{11}$

In addition to medical and physical test variables, our enlistment data include cognitive ability as well as a measure of noncognitive ability. Cognitive ability is measured through tests of logical, verbal, spatial and technical skills. Based on his results on these tests, the individual has been assigned a number on a nine-point scale, approximating a normal distribution. We choose to normalize this number by birth year using all individuals with non-missing data on this variable.

Like cognitive ability, noncognitive ability is measured on a scale between 1 and 9 , approximating a normal distribution. The assignment of this number is done by a psychologist, based on a semi-structured interview lasting for about 25 minutes, whose objective is "to assess

\footnotetext{
${ }^{10}$ However, individuals assigned a "Y" may be required to undergo non-military education.

${ }^{11}$ While this simple transformation allows us to exploit the large variation in data, it may also be of interest to explore the possibility of non-linear effects of overall health. We therefore also investigate specifications with dummies indicating “perfect health” (A) and "poor health” (Y or Z).
} 
the conscript's ability to cope with the psychological requirements of the military service and, in extreme case, war” (Lindqvist and Vestman, 2009). This in particular implies an assessment of personal characteristics such as willingness to assume responsibility, independence, outgoing character, persistence, emotional stability and power of initiative. It is not really clear as to what extent this measure is comparable with other measures of noncognitive ability used in the literature, but we consider it of interest to include this as a control since health and noncognitive ability (as defined in this way) may have common determinants and might thus be importantly correlated. ${ }^{12}$ We proceed similarly as for cognitive ability and standardize the noncognitive ability variable by birth year using all individuals with non-missing data. It has previously been shown (Lindqvist and Vestman, 2009) that both our cognitive and noncognitive measures strongly predict adult earnings in the population of Swedish males, so they both seem to be adequate indicators of ability.

Some individuals have missing values on one or several physical test variables, on parental education, on cognitive ability, or on noncognitive ability. In our OLS regressions, we use sample averages and create a binary variable taking on the value one when there is missing information on a variable. Similarly, for our twin-fixed effects estimates, we make twin differences equal zero and add a binary variable taking on the value one when there is missing data on one of the twins.

\subsection{Sample constructions}

We now turn to the construction of our main sample. First, we exclude 744 individuals for which

\footnotetext{
${ }^{12}$ Previous measures of noncognitive ability used in the literature have, for example, included "the degree of control individuals feel they possess over their life” (see e.g. Heckman et al., 2006).
} 
health status has not been assessed or reported $(15 \%) .{ }^{13}$ Of the remaining individuals, 66 (2 \%) are dropped due to missing information on educational attainment. Finally, we exclude individuals for which the co-twin is not in the sample ( $8 \%$ ), giving us a sample including 3,748 MZ twin individuals.

Table 1 provides descriptive statistics for this sample. Hypertension is the by far most prevalent health problem, followed by musculoskeletal conditions. Individuals on average obtain about 12 years of education, with a standard deviation of 2 .

Included in the descriptive statistics is also the number of twin pairs differing with respect to the variables. As can be seen, in most cases where an individual has a certain health problem, his co-twin does not have the same condition. This is quite important for our chances to detect any possible effect of health on educational attainment, as the explanatory variables in our twin-differenced equations will only differ from zero, and thus contribute to the estimate, when one of the twins is diagnosed with the condition in question, and one is not. Most importantly, there are as many as 747 twin pairs differing in global health status. This is much higher than the number of pairs differing in educational attainment typically encountered in studies using twins to estimate the returns to schooling. For example, in the samples used by Ashenfelter and Krueger (1994) and Miller (1995), only 76 and 265 MZ twin pairs differ in educational attainment, respectively. Even for particular health problems, the number of twin pairs differing is quite substantial. For example, there are as many as 419 twin pairs where one of the twins has hypertension, 322 pairs where one of the twins has a musculoskeletal condition, and 176 pairs

\footnotetext{
${ }^{13}$ More specifically, individuals are excluded if global health is missing. It is not possible to determine whether there is missing information on specific health conditions. However, for individuals reported to suffer from specific health conditions, data on global health is always available.
} 
where one of the twins has a respiratory condition.

\subsection{Econometric specifications}

As baselines, we run pooled OLS regressions, that is, regressions without twin-fixed effects:

(3.1) $S_{i j}=\alpha+\beta X_{i j}+\varepsilon_{i j}$

In this equation, $\mathrm{X}$ is a vector including one or several health variables and, in some specifications, controls for cognitive and noncognitive ability. Running such regressions, we determine whether correlations between health and schooling are present in our data.

However, in line with equation (2.5), our main goal is to determine whether there are within-twins relationships between health and educational attainment. We thus take twin differences and estimate relationships of the following form using OLS:

$$
S_{i 1}-S_{i 2}=\beta\left(X_{i 1}-X_{i 2}\right)+\varepsilon_{1}-\varepsilon_{2} .
$$

This gives the twin fixed effects estimator of $\beta$. Our point of interest is whether the health components of $\beta$ in this equation are equal to zero or not.

Since we investigate a large number of indicators of early health and their possible relationships with educational attainment, it wouldn't be unlikely if some coefficients wrongly turned out statistically significant. For this reason, we apply F-tests to all our regressions including more than one health variable and test for the presence of any relationship between early health and educational attainment. Any such relationship within twins would suggest a 
potential problem for the literature using the twin-approach to obtain estimates of the returns to schooling.

\section{Results}

The sections below separately report the results for the following classes of outcomes: Global health, health conditions, and physical test variables. In every section, both pooled OLS and twin-fixed effects regressions are run. ${ }^{14}$

\subsection{Global health}

The regression results when using our (linear) global health measure are shown in Table 2. As can be seen in column A, there is a strong relationship between global health and educational attainment at the pooled level, at least when no controls are being included. On average, ten steps in global health, which is the difference between "perfect health" and a health status just a little better than required for military enlistment, corresponds to about half a year less education.

In column B, cognitive ability is controlled for. The relationship between global health and educational attainment is now reduced to a tenth, and is not statistically significant. That is, for a given level of cognitive ability, there is no evidence a relationship between health and educational attainment. Column $\mathrm{C}$ then adds a control for noncognitive ability. Somewhat surprisingly, the results show that for a given level of (cognitive and noncognitive) ability, individuals in worse health choose to undertake somewhat more schooling than others, a result

\footnotetext{
${ }^{14}$ Using the Hausman (1978) test, we have also investigated whether random effects specifications would have been appropriate. It turns out that random effects specifications can be rejected in all cases at the 5 percent significance level.
} 
that is significant at the 5 percent level. Our results could be interpreted to suggest that the effects of health work quite strongly through cognitive and noncognitive abilities, or otherwise, that health is simply correlated with cognitive and noncognitive ability, but not necessarily causally related to these.

Columns D-F include twin-pair fixed effects, that is, the relationship is estimated within twins. Irrespective of whether we control for abilities, it is apparent that there is no evidence of a relationship between health status and educational attainment within twin pairs. In particular, the strong relationship previously obtained without controls for cognitive and noncognitive ability is eliminated (see column D), both economically and statistically, and the coefficient estimate equals -0.078 . It is not reasonable to believe that such a large drop would be explained by measurement errors. While cognitive and noncognitive ability are still strongly significant with the inclusion of twin-fixed effects (see column E and F), our results show that the correlations between global health and educational attainment obtained in our sample of twins may well be completely explained by genetic and family environmental effects, which are constant within any given twin pair or, alternatively, that there may be compensating behaviors within twin pairs so that schooling is not significantly affected by health status. ${ }^{15}$

\footnotetext{
${ }^{15}$ In Appendix 1, we investigate specifications where we instead of the linear global health measure use dummies for "perfect health" and "poor health". Just like for our linear global health measure, there is strong evidence of a relationship between health and educational attainment at the pooled level, as shown by the F-statistics, both without controls for ability and with controls for both cognitive and noncognitive ability. But such evidence is not obtained within twin pairs. In column D and column E, where noncognitive is not controlled for, "perfect health" is significant at the 10 percent level; however, the F-tests based on the hypothesis that both health indicators have zero effect could not be rejected.
} 


\subsection{Health conditions}

We now turn to our results using classes of specific health conditions, which are displayed in Table 3. Column A shows that, at the pooled level, there seem to be several different mechanisms at play. First of all, there is a very strong negative relationship between mental illness and educational attainment, amounting to about 1.5 years of schooling. Moreover, individuals with musculoskeletal conditions obtain about 0.3 years less schooling, whereas individuals with respiratory conditions obtain a half year more of education on average. An F-test based on the null hypothesis that health diagnoses and educational attainment are unrelated was rejected at all levels.

Controlling for cognitive and noncognitive abilities (columns B and C) lowers the significance of these coefficients, economically as well as statistically, which may, again, reflect that part of the effect of bad health on education work through these types of skills. In addition, the coefficient on skin conditions becomes significant at the 10 percent level in the specifications including ability controls, with a positive coefficient of 0.3. Again, our F-statistics strongly suggest the presence of a relationship between health and educational attainment, both when we control for cognitive ability (column B) and when we control for both cognitive and noncognitive ability (column C).

Columns D-F show our regression results when applying the twin fixed effects estimator. Even without ability controls, there is now little evidence of any relationship between health and educational attainment, as the coefficients on mental, musculoskeletal and respiratory conditions all approach zero and become insignificant. This is particularly striking for mental conditions (which for example assumes a highly insignificant value of -0.007 in column D) given the large coefficient previously obtained. The only class of health conditions to be significant when 
applying the twin fixed effects estimators is skin conditions (column D), now with a negative coefficient. This significant coefficient may well be due to chance, however; our F-tests do not allow us to reject the possibility that there is no relationship between health conditions and educational attainment at any reasonable level of significance in any of the specifications including twin-fixed effects. ${ }^{16}$

\subsection{Physical test variables}

Running regressions using our physical test variables, a number of interesting results show up, as displayed in Table 4. At the pooled level, having low physical capacity and being overweight is related to lower educational attainment, irrespective of the specification. In particular, the effect of low physical capacity is very strong, with a coefficient of -1.1 in the specification without ability controls (column A). This is almost of the same magnitude as the coefficient on mental conditions previously obtained. Without the controls for ability, there is also evidence that being short, overweight, having low visual acuity or low hearing acuity is related to lower educational attainment. The inclusions of cognitive and noncognitive abilities have the effects of reducing the significant coefficients in magnitude.

Having weak handgrip strength is positively related to educational attainment at the pooled level, a relationship that is strengthened when ability is controlled for and not even statistically significant when no ability control has been included. Finally, hypertension is the

\footnotetext{
${ }^{16}$ Appendix 2 investigates the relationship between educational attainment and our classes of health conditions when only including a maximum of two conditions per person (the first two reported). This restriction has apparently little effect on the results. There is some, statistically weak, evidence that skin and digestive conditions would be related to educational attainment within twin pairs when cognitive and noncognitive abilities are not controlled for; however, we cannot reject the hypothesis that all health coefficients jointly equal zero.
} 
only of our physical test variables to be completely unrelated to educational attainment. This finding is particularly interesting given the fact that hypertension is the most common of all health problems encountered in our sample.

The relationships are then estimated within twins (see columns D-F in Table 4). As before, there is now little evidence of health as a predictor of educational attainment. All health coefficients have become statistically insignificant, and generally approach values close to zero. The only exception is "short", which shows up with a coefficient of -0.35 in the specification without controls for cognitive and noncognitive ability, although not being statistically significant. In particular, note that the previously strong effect of low physical capacity has completely vanished. Regardless of whether controls for cognitive and noncognitive ability are included, it is not possible to reject the F-tests of jointly zero health coefficients at any reasonable level.

\subsection{Cohort and interactive effects}

Previous studies have provided some evidence that health status may interact with personal characteristics such as socioeconomic background. For example, based on sibling comparisons, Loughran et al. (2004) document interactive effects between birth weight and mother's labor supply on math and reading scores. In Appendix 3, we investigate the possibility of interaction effects between health and socioeconomic background, and in Appendix 4 we investigate whether there are interactive effects between health and cognitive and noncognitive ability. Again, these tables show that there is strong evidence of relationships between health (and interactions with health) and educational attainment at the pooled level, but there is little evidence of such relationships within twin pairs. The p-values from the F-tests are highly 
significant in virtually all specifications without twin-fixed effects, whereas the hypothesis of a non-relationship between health and educational attainment cannot be rejected at the 10 percent level in any specification where twin-fixed effects have been included.

Appendix 5 investigates the possibility of cohort-specific relationships between health and educational attainment, using interactions between our health variables and birth decade. Our regressions based on global health and physical test variables confirm our previous conclusions that is, there is no evidence of a relationship between health and educational attainment within twin pairs. This pattern is broken, however, by Table A5.2, where we do obtain statistical evidence of a within-twins relationship between health conditions and educational attainment. As can be seen, some of the interactions between health conditions and being born in the 50's as well as the F-statistics yield significant results in these specifications, indicating a possible relationship between health and schooling for individuals born in the 1950's.

In an attempt to explore whether these relationships are valid or may simply have been due to chance, we re-run the regressions of Table A5.2 but also include dizygotic twins, and individuals of unknown zygosity (see Table A5.4). This means that a much larger sample is used, consisting of 10,436 individuals. Doing this, no evidence of a relationship between health and educational attainment is obtained, as only one cohort-health interaction is still statistically significant (born in the 1950's * having a musculoskeletal condition) and none of the F-statistics yield significant results at any reasonable level within twins. These findings cast some doubt on the corresponding results obtained for MZ twins only, because those would then have to be explained either by cohort-specific behavioral differences between MZ and DZ twin pairs, or by cohort-specific genetic effects working in the opposite direction as the health conditions. 


\section{Conclusion}

On the whole, we obtain no evidence of a relationship between health status and educational attainment when employing twin design. This conclusion holds both with and without controls for cognitive and noncognitive ability. The fact that a large number of strong effects are found when running pooled OLS regressions shows that these non-findings cannot simply be blamed on a lack of correlation between health and educational attainment.

We find that the conclusion is robust in that it does not change when using a non-linear instead of a linear measure of global health, when including a maximum of two health conditions per person, or when including interactions between health and socioeconomic background, or between health and cognitive and noncognitive ability. Investigating the possibility of cohortspecific effects, we do obtain statistical evidence of a relationship between health conditions and educational attainment within MZ twin pairs for individuals born in the 1950's; however, the fact that no such evidence is obtained when investigating this relationship within twin pairs in general casts doubt on the validity of those results.

Our results could be explained in different ways. The most obvious is that the raw correlations between health and educational attainment encountered in our sample are completely driven by genes and growing up environment, factors that are differenced out by the twin design. Alternatively, parents may compensate for health differences between the twins, so that schooling is not affected by poor health within twin pairs. Similarly, due to the closeness of a twin relationship, twins may influence each other in their schooling investment decision so that both end up with the same educational attainment, irrespective of their health status. One should also note that our study is based on Sweden, a country where healthcare as well as higher education is more or less free of charge, and where income inequalities are much lower than in, 
for example, the US. As a result, some of the potential mechanisms whereby health affects schooling may not be in place. This would partly be in line with Black et al. (2007) who find comparatively small effects of birth weight on educational attainment using data from Norway. In any case, educational attainment is only one aspect of socioeconomics, and our results from this study should thus not be interpreted as suggesting that early health has no long-run effects on socioeconomic status in general.

The assumption of educational attainment being exogenous within twin pairs is crucial in the literature using twins to estimate the returns to schooling. Previous literature has provided evidence that educational attainment is related to birth weight (e.g. Behrman and Rosenzweig, 2004; Black et al., 2007), parental investments (Lundborg, 2010), and cognitive ability at the age of 18 (Sandewall et al., 2009). This finding regarding cognitive ability is strongly confirmed by our regressions. On the other hand, we obtain little evidence of schooling being endogenous to health status at the age of 18 , and so our findings suggest that there is no apparent need for studies using twins to estimate the returns to schooling to take measures of early life health into account. 


\section{References}

Angrist, Joshua D. and Allan B. Krueger (1991), “Does compulsory school attendance affect schooling and earnings?”, Quarterly Journal of Economics, 106: 979-1014.

Ashenfelter, Orley and Alan B. Krueger (1994), "Estimates of the economic return to schooling from a new sample of twins”, American Economic Review, 84: 1157-73.

Ashenfelter, Orley and Cecilia Rouse (1998), “Income, schooling and ability: Evidence from a new sample of identical twins”, Quarterly Journal of Economics, 113: 253-84.

Ashenfelter, Orley and David Zimmerman (1997), "Estimates of the return to schooling from sibling data: fathers, sons and brothers”, Review of Economics and Statistics, 79: 1-9.

Behrman, Jere R. and Mark R. Rosenzweig (2004), “Returns to Birth weight”, Review of Economics and Statistics, 86: 586-601.

Black, Sandra E., Paul J. Devereux, Kjell G. Salvanes (2007), “From the cradle to the labor market? The effect of birth weight on adult outcomes”, Quarterly Journal of Economics, 122: 409-39.

Bonjour, Dorothe, Lynn Cherkas, Jonathon Haskel, Denise Hawkes and Tim Spector (2003), "Returns to education: evidence from UK twins", American Economic Review, 93: 1799-1812. Bound, John and Gary Solon (1999), “Double trouble: on the value of twins-based estimation of the return to schooling”, Economics of Education Review, 18: 169-82.

Bozzoli, Carlos G., Angus S. Deaton and Climent Quintana-Domeque (2008), “Adult height and childhood disease”, Working Paper 2008-25, Fundación de Estudios de Economía Aplicada (FEDEA). 
Card, David (1999), “The causal effect of education on earnings”. In Handbook of labor economics, Vol. 3A, ed. Orley Ashenfelter and David Card. Amsterdam, NL: North Holland.

Case, Anne, Angela Fertig and Christina Paxson (2005), "The lasting impact of childhood health and circumstance”, Journal of Health Economics, 24: 365-89.

Currie, Janet, Mark Stabile, Phongsack Manivong and Leslie L. Roos (2010), "Child health and young adult outcomes”, Journal of Human Resources, 45: 517-48.

Hausman, Jerry A. (1978), “Specification tests in econometrics”, Econometrica, 46: 1251-71.

Heckman, James J., Jora Stixrud and Sergio Urzua (2006), “The effects of cognitive and noncognitive abilities on labor market outcomes and social behavior”, Journal of Labor Economics, 3: 411-82.

Isacsson, Gunnar (1999), "Estimates of the return to schooling in Sweden from a large sample of twins”, Labour Economics, 6: 471-89.

Isacsson, Gunnar (2004), “Estimating the Economic Return to Educational Levels Using Data on Twins”, Journal of Applied Econometrics, 19: 99-119.

Koning, Pierre, Dinand Webbink, Suncica Vujic and Nicholas G. Martin (2010), “The effect of childhood conduct disorder on human capital”, IZA Discussion Paper no. 4940, Institute for the Study of Labor (IZA).

Lichtenstein, Paul, Ulf de Faire, Birgitta Floderus, Magnus Svartengren, Pia Svedberg and Nancy L. Pedersen (2002), ”The Swedish Twin Registry: A unique resource for clinical, epidemiological and genetic studies”, Journal of Internal Medicine, 252: 184-205.

Lindqvist, Erik and Roine Vestman (2009), “The Labor Market Returns to Cognitive and Noncognitive Ability: Evidence from the Swedish Enlistment”, IFN Working Paper 794, 
Research Institute of Industrial Economics (IFN).

Loughran, David S., Ashlesha Datar and M. Rebecca Kilburn (2004), “The interactive effect of birth weight and parental investment on child test scores”, Rand Working Paper no. 168, Rand Corporation Publications Department.

Lundborg, Petter (2010), “Why are identical twins not identical? The importance of early life environment for the educational achievement of twins”, unpublished manuscript, Lund University.

Maluccio, John (1998), “Endogeneity of schooling in the wage function”, FCND discussion papers, no. 54, International Food Policy Research Insititute (IFPRI).

Mannuzza, Salvatore and Rachel Klein (2000), “Long-term prognosis in attentiondeficit/hyperactive disorder”, Child and Adolescent Psychiatric Clinics of North America, 9: $711-26$.

Miller, Paul, Charles Mulvey and Nick Martin (1995), "What do twins studies reveal about the economic returns to education? A comparison of Australian and U.S. findings”, American Economic Review, 85: 586-99.

Miller, Paul, Charles Mulvey and Nick Martin (2005), "Birth weight and schooling and earnings: estimates from a sample of twins”, Economics Letters, 86: 387-92.

Oreopoulos, Philip (2006), “Estimating average and local average treatment effects of education when compulsory schooling laws really matter”, American Economic Review, 96: 152-75.

Oreopoulos, Philip, Mark Stabile, Randy Walld and Leslie L. Roos (2008), "Short-, medium-, and long-term consequences of poor infant health: an analysis using siblings and twins”, Journal of Human Resources, 43: 88-138. 
Pischke, Jörn-Steffen and Till von Wachter (2008), “Zero returns to compulsory schooling in Germany: Evidence and Interpretation”, Review of Economics and Statistics, 3: 592-8.

Royer, Heather (2009), "Separated at girth: US twin estimates of the effects of birth weight", American Economic Journal, Applied Economics, 1: 49-85.

Sandewall, Örjan, David Cesarini and Magnus Johannesson (2009), “The co-twin methodology and returns to schooling - testing a critical assumption”, IFN Working Paper no. 806, Research Institute of Industrial Economics (IFN).

Smith, James P. (2009), “The impact of childhood health on adult labor market outcomes”, Review of Economics and Statistics, 91: 478-89.

Tancready, Caroline M. And R. Chris Fraley (2006), “The nature of adult twin relationships: an attachment-theoretical perspective”, Journal of Personality and Social Psychology, 90: 78-93. WHO (1967), Manual of the international statistical classification of diseases, injuries, and causes of death, eighth revision. Geneva: World Health Organization.

WHO (1977), Manual of the international statistical classification of diseases, injuries, and causes of death, ninth revision, 1. Geneva: World Health Organization.

WHO (1978), Manual of the international statistical classification of diseases, injuries, and causes of death, ninth revision, 2. Geneva: World Health Organization. 
Tables 
Table 1: Descriptive statistics

\begin{tabular}{|c|c|c|c|}
\hline NON-BINARY VARIABLES & MEAN (STD) & MISSING OBSERVATIONS & TWIN PAIRS DIFFERING \\
\hline Years of schooling & $12.434(2.097)$ & - & 908 \\
\hline Global health & $2.374(4.031)$ & - & 747 \\
\hline Cognitive ability & $0.092(0.965)$ & 61 & 1,185 \\
\hline Noncognitive ability & $0.076(0.973)$ & 162 & 1,088 \\
\hline Father's years of schooling & $10.659(3.078)$ & 1,100 & - \\
\hline Mother's years of schooling & $10.745(2.917)$ & 719 & - \\
\hline BINARY VARIABLES & INCIDENCE & MISSING OBSERVATIONS & TWIN PAIRS DIFFERING \\
\hline Mental & 140 & - & 74 \\
\hline Circulatory & 119 & - & 91 \\
\hline Musculoskeletal & 432 & - & 322 \\
\hline Digestive & 114 & - & 88 \\
\hline Skin & 184 & - & 114 \\
\hline Respiratory & 318 & - & 176 \\
\hline Injuries and poisonings & 180 & - & 156 \\
\hline Low physical capacity & 153 & 526 & 86 \\
\hline Weak handgrip strength & 144 & 387 & 90 \\
\hline Hypertension & 757 & 106 & 419 \\
\hline Overweight & 186 & 63 & 88 \\
\hline Short & 167 & 63 & 41 \\
\hline Low visual acuity & 186 & 75 & 117 \\
\hline Low hearing acuity & 196 & 76 & 141 \\
\hline
\end{tabular}

Notes: The sample includes 3,478 individuals. "Incidence" is the number of individuals diagnosed with the condition in question. "Twin pairs differing" is the number of twin pairs where one of the twins is diagnosed with the condition in question, and one is not. 
Table 2: Global health and educational attainment

\begin{tabular}{|c|c|c|c|c|c|c|}
\hline VARIABLES & A & B & C & D & $\mathrm{E}$ & $\mathrm{F}$ \\
\hline \multirow[t]{2}{*}{ Global health $\left({ }^{*} 10\right)$} & $-0.464^{\star \star \star}$ & 0.043 & 0.230 ** & -0.078 & -0.112 & -0.075 \\
\hline & $(0.093)$ & $(0.008)$ & $(0.091)$ & $(0.095)$ & $(0.010)$ & $(0.101)$ \\
\hline \multirow[t]{2}{*}{ Cognitive ability } & & $1.278^{\star \star \star}$ & $1.171^{\star \star *}$ & & $0.416^{\star \star \star}$ & $0.393^{* * *}$ \\
\hline & & $(0.034)$ & $(0.036)$ & & $(0.064)$ & $(0.065)$ \\
\hline \multirow[t]{2}{*}{ Noncognitive ability } & & & $0.301^{\star \star \star}$ & & & $0.123^{\star \star}$ \\
\hline & & & $(0.038)$ & & & $(0.052)$ \\
\hline R-squared & 0.007 & 0.283 & 0.296 & 0.000 & 0.024 & 0.028 \\
\hline Twin-fixed effects & NO & NO & NO & YES & YES & YES \\
\hline Observations & \multicolumn{6}{|c|}{3,748} \\
\hline
\end{tabular}

Notes: Standard errors in parentheses. * indicates $10 \%$ significance, ${ }^{* *} 5 \%$ significance, and ${ }^{* * *} 1 \%$ significance. 
Table 3: Health conditions and educational attainment

\begin{tabular}{|c|c|c|c|c|c|c|}
\hline VARIABLES & $A$ & B & C & $\mathrm{D}$ & $E$ & $\mathrm{~F}$ \\
\hline \multirow[t]{2}{*}{ Mental } & $-1.541^{\star \star \star}$ & $-0.723^{\star \star \star}$ & $-0.453^{\star \star \star}$ & -0.007 & 0.015 & 0.123 \\
\hline & $(0.196)$ & $(0.169)$ & $(0.173)$ & $(0.194)$ & $(0.192)$ & $(0.196)$ \\
\hline \multirow[t]{2}{*}{ Circulatory } & -0.228 & 0.083 & 0.082 & 0.137 & 0.166 & 0.166 \\
\hline & $(0.212)$ & $(0.181)$ & $(0.180)$ & $(0.175)$ & $(0.173)$ & $(0.173)$ \\
\hline \multirow[t]{2}{*}{ Musculoskeletal } & $-0.288^{\star *}$ & -0.125 & -0.081 & 0.099 & 0.110 & 0.118 \\
\hline & $(0.116)$ & $(0.099)$ & $(0.099)$ & $(0.094)$ & $(0.093)$ & $(0.093)$ \\
\hline \multirow[t]{2}{*}{ Digestive } & -0.187 & -0.053 & 0.012 & -0.290 & -0.266 & -0.243 \\
\hline & $(0.216)$ & $(0.185)$ & $(0.184)$ & $(0.178)$ & $(0.176)$ & $(0.176)$ \\
\hline \multirow[t]{2}{*}{ Skin } & 0.024 & $0.262^{*}$ & $0.293^{\star *}$ & $-0.314^{\star *}$ & -0.253 & -0.249 \\
\hline & $(0.172)$ & $(0.147)$ & $(0.146)$ & $(0.157)$ & $(0.156)$ & $(0.155)$ \\
\hline \multirow[t]{2}{*}{ Respiratory } & $0.527^{\star \star \star}$ & $0.343^{\star * \star}$ & $0.351^{\star \star \star}$ & -0.074 & -0.073 & -0.058 \\
\hline & $(0.133)$ & $(0.114)$ & $(0.113)$ & $(0.126)$ & $(0.125)$ & $(0.125)$ \\
\hline \multirow[t]{2}{*}{ Injuries and poisonings } & 0.130 & 0.213 & $0.247^{\star}$ & -0.011 & -0.034 & -0.021 \\
\hline & $(0.174)$ & $(0.148)$ & $(0.147)$ & $(0.135)$ & $(0.134)$ & $(0.134)$ \\
\hline \multirow[t]{2}{*}{ Cognitive ability } & & $1.253^{\star * *}$ & $1.164^{\star \star \star}$ & & $0.414^{\star \star \star}$ & $0.388^{* * *}$ \\
\hline & & $(0.034)$ & $(0.036)$ & & $(0.065)$ & $(0.066)$ \\
\hline \multirow[t]{2}{*}{ Noncognitive ability } & & & $0.253^{\star \star \star}$ & & & $0.134^{\star \star *}$ \\
\hline & & & $(0.037)$ & & & $(0.052)$ \\
\hline R-squared & 0.024 & 0.290 & 0.299 & 0.005 & 0.028 & 0.032 \\
\hline F-test & $0.000^{\star \star \star}$ & $0.000^{\star \star \star}$ & $0.000^{\star \star \star}$ & 0.237 & 0.332 & 0.322 \\
\hline Twin-fixed effects & NO & NO & NO & YES & YES & YES \\
\hline
\end{tabular}

Notes: Standard errors in parentheses. * indicates $10 \%$ significance, $* * 5 \%$ significance, and $* * * 1 \%$ significance.

"F-test" is the p-value from an F-test based on the null hypothesis that all health coefficients equal zero. 
Table 4: Physical test variables and educational attainment

\begin{tabular}{|c|c|c|c|c|c|c|}
\hline VARIABLES & $A$ & $B$ & $C$ & $\mathrm{D}$ & $E$ & $\mathrm{~F}$ \\
\hline \multirow[t]{2}{*}{ Low physical capacity } & $-1.111^{\star \star *}$ & $-0.566^{\star \star \star}$ & $-0.377^{\star \star}$ & -0.034 & 0.023 & 0.041 \\
\hline & $(0.189)$ & $(0.161)$ & $(0.162)$ & $(0.180)$ & $(0.179)$ & $(0.179)$ \\
\hline \multirow[t]{2}{*}{ Weak handgrip strength } & 0.123 & $0.453^{\star \star \star}$ & $0.521^{\star \star \star}$ & -0.011 & 0.025 & 0.048 \\
\hline & $(0.194)$ & $(0.166)$ & $(0.165)$ & $(0.177)$ & $(0.175)$ & $(0.175)$ \\
\hline \multirow[t]{2}{*}{ Hypertension } & 0.001 & 0.028 & 0.018 & 0.128 & 0.122 & 0.127 \\
\hline & $(0.093)$ & $(0.079)$ & $(0.078)$ & $(0.082)$ & $(0.081)$ & $(0.081)$ \\
\hline \multirow[t]{2}{*}{ Overweight } & $-0.655^{\star \star \star}$ & $-0.385^{\star \star \star}$ & $-0.368^{\star \star}$ & -0.073 & -0.041 & -0.030 \\
\hline & $(0.171)$ & $(0.145)$ & $(0.144)$ & $(0.179)$ & $(0.177)$ & $(0.177)$ \\
\hline \multirow[t]{2}{*}{ Short } & $-0.572^{\star \star \star}$ & -0.171 & -0.160 & -0.352 & -0.270 & -0.252 \\
\hline & $(0.181)$ & $(0.154)$ & $(0.153)$ & $(0.261)$ & $(0.259)$ & $(0.259)$ \\
\hline \multirow[t]{2}{*}{ Low visual acuity } & $-0.370^{\star \star}$ & -0.127 & -0.112 & -0.068 & 0.001 & 0.006 \\
\hline & $(0.170)$ & $(0.145)$ & $(0.144)$ & $(0.155)$ & $(0.154)$ & $(0.154)$ \\
\hline \multirow[t]{2}{*}{ Low hearing acuity } & $-0.398^{\star \star}$ & -0.197 & -0.185 & -0.127 & -0.128 & -0.142 \\
\hline & $(0.166)$ & $(0.142)$ & $(0.141)$ & $(0.141)$ & $(0.140)$ & $(0.140)$ \\
\hline \multirow[t]{2}{*}{ Cognitive ability } & & $1.249 * \star \star$ & $1.149^{\star * \star}$ & & $0.414^{\star \star \star}$ & $0.387^{* * *}$ \\
\hline & & $(0.033)$ & $(0.036)$ & & $(0.065)$ & $(0.066)$ \\
\hline \multirow[t]{2}{*}{ Noncognitive ability } & & & $0.267^{\star \star \star}$ & & & $0.132^{\star \star \star}$ \\
\hline & & & $(0.036)$ & & & $(0.051)$ \\
\hline R-squared & 0.040 & 0.304 & 0.314 & 0.006 & 0.027 & 0.031 \\
\hline F-test & $0.000^{\star \star \star}$ & $0.000 * \star \star$ & $0.001^{\star * \star}$ & 0.590 & 0.748 & 0.714 \\
\hline Twin-fixed effects & NO & NO & NO & YES & YES & YES \\
\hline Observations & & & & & & \\
\hline
\end{tabular}

Notes: Standard errors in parentheses. * indicates $10 \%$ significance, ** $5 \%$ significance, and $* * * 1 \%$ significance.

"F-test" is the p-value from an F-test based on the null hypothesis that all health coefficients equal zero. 
Appendix 1: An alternative global health measure Table A1: Global health and educational attainment

\begin{tabular}{|c|c|c|c|c|c|c|}
\hline VARIABLES & A & $B$ & C & D & $E$ & $\mathrm{~F}$ \\
\hline \multirow[t]{2}{*}{ Global health $=\mathrm{A}$} & $0.169^{\star *}$ & -0.009 & -0.102 & $0.137^{*}$ & $0.131^{*}$ & 0.114 \\
\hline & $(0.086)$ & $(0.073)$ & $(0.073)$ & $(0.077)$ & $(0.076)$ & $(0.077)$ \\
\hline \multirow[t]{2}{*}{ Global health $=Y$ or $Z$} & $-0.351^{\star \star}$ & 0.108 & $0.296^{\star \star}$ & 0.061 & -0.023 & 0.010 \\
\hline & $(0.139)$ & $(0.127)$ & $(0.135)$ & $(0.129)$ & $(0.138)$ & $(0.143)$ \\
\hline \multirow[t]{2}{*}{ Cognitive ability } & & $1.279 \star \star \star$ & $1.169^{\star \star \star}$ & & $0.417^{\star \star \star}$ & $0.394^{\star \star \star}$ \\
\hline & & $(0.034)$ & $(0.036)$ & & $(0.064)$ & $(0.065)$ \\
\hline \multirow[t]{2}{*}{ Noncognitive ability } & & & $0.311^{\star \star \star}$ & & & $0.120^{\star *}$ \\
\hline & & & $(0.038)$ & & & $(0.052)$ \\
\hline R-squared & 0.005 & 0.283 & 0.296 & 0.002 & 0.025 & 0.029 \\
\hline F-test & $0.000^{\star \star *}$ & 0.616 & $0.008^{\star \star \star}$ & 0.207 & 0.179 & 0.309 \\
\hline Twin-fixed effects & NO & NO & NO & YES & YES & YES \\
\hline Observations & \multicolumn{6}{|c|}{3,748} \\
\hline
\end{tabular}

Notes: Standard errors in parentheses. * indicates $10 \%$ significance, ** $5 \%$ significance, and *** $1 \%$ significance. "F-test" is the p-value from an F-test based on the null hypothesis that both health indicators have zero effect. 
Appendix 2: Not more than two health conditions per person

Table A2: Health conditions and educational attainment. Max two conditions

\begin{tabular}{|c|c|c|c|c|c|c|}
\hline VARIABLES & A & B & C & D & $\mathrm{E}$ & $\mathrm{F}$ \\
\hline \multirow[t]{2}{*}{ Mental } & $-1.655^{\star \star *}$ & $-0.781^{\star \star *}$ & $-0.495^{\star \star *}$ & -0.080 & -0.081 & 0.020 \\
\hline & $(0.216)$ & $(0.186)$ & $(0.189)$ & $(0.202)$ & $(0.199)$ & $(0.203)$ \\
\hline \multirow[t]{2}{*}{ Circulatory } & -0.210 & 0.095 & 0.096 & 0.124 & 0.138 & 0.132 \\
\hline & $(0.222)$ & $(0.189)$ & $(0.188)$ & $(0.178)$ & $(0.176)$ & $(0.176)$ \\
\hline \multirow[t]{2}{*}{ Musculoskeletal } & $-0.268^{\star \star}$ & -0.080 & -0.022 & 0.107 & 0.120 & 0.132 \\
\hline & $(0.120)$ & $(0.102)$ & $(0.102)$ & $(0.096)$ & $(0.095)$ & $(0.095)$ \\
\hline \multirow[t]{2}{*}{ Digestive } & -0.224 & -0.009 & 0.058 & $-0.331^{*}$ & $-0.307^{*}$ & -0.289 \\
\hline & $(0.224)$ & $(0.191)$ & $(0.190)$ & $(0.188)$ & $(0.186)$ & $(0.186)$ \\
\hline \multirow[t]{2}{*}{ Skin } & 0.047 & $0.312^{\star \star}$ & $0.348^{\star \star}$ & $-0.267^{\star}$ & -0.211 & -0.207 \\
\hline & $(0.176)$ & $(0.150)$ & $(0.150)$ & $(0.160)$ & $(0.159)$ & $(0.159)$ \\
\hline \multirow[t]{2}{*}{ Respiratory } & $0.487^{\star \star \star}$ & $0.340^{\star \star \star}$ & $0.355^{\star \star \star}$ & -0.088 & -0.075 & -0.059 \\
\hline & $(0.136)$ & $(0.116)$ & $(0.116)$ & $(0.127)$ & $(0.126)$ & $(0.126)$ \\
\hline \multirow[t]{2}{*}{ Injuries and poisonings } & 0.167 & $0.259 *$ & $0.292^{\star}$ & 0.020 & -0.004 & 0.009 \\
\hline & $(0.178)$ & $(0.152)$ & $(0.151)$ & $(0.138)$ & $(0.137)$ & $(0.137)$ \\
\hline \multirow[t]{2}{*}{ Cognitive ability } & & $1.257^{\star \star \star}$ & $1.165^{\star \star \star}$ & & $0.414^{\star \star \star}$ & $0.387^{\star \star *}$ \\
\hline & & $(0.033)$ & $(0.036)$ & & $(0.065)$ & $(0.066)$ \\
\hline \multirow[t]{2}{*}{ Noncognitive ability } & & & $0.257^{\star \star \star}$ & & & $0.132^{\star \star}$ \\
\hline & & & $(0.037)$ & & & $(0.052)$ \\
\hline R-squared & 0.024 & 0.290 & 0.300 & 0.005 & 0.028 & 0.031 \\
\hline F-test & $0.000 * \star \star$ & $0.000^{\star \star \star}$ & $0.000^{\star * \star}$ & 0.291 & 0.387 & 0.415 \\
\hline Twin-fixed effects & NO & NO & NO & YES & YES & YES \\
\hline Observations & \multicolumn{6}{|c|}{3,748} \\
\hline
\end{tabular}

Notes: Standard errors in parentheses. * indicates $10 \%$ significance, ** $5 \%$ significance, and *** $1 \%$ significance.

"F-test" is the p-value from an F-test based on the null hypothesis that all health coefficients equal zero. 


\section{Appendix 3: Interactions with socioeconomic status}

Table A3.1: Global health and educational attainment. Interactions with parental educational attainment

\begin{tabular}{|c|c|c|c|c|c|c|}
\hline VARIABLES & $A$ & $B$ & $C$ & $\mathrm{D}$ & $E$ & $\mathrm{~F}$ \\
\hline \multirow[t]{2}{*}{ Global health $\left({ }^{\star} 10\right)$} & $-0.410^{\star \star *}$ & $-0.318^{\star}$ & $-0.388^{\star \star}$ & 0.041 & 0.193 & 0.196 \\
\hline & $(0.147)$ & $(0.167)$ & $(0.171)$ & $(0.166)$ & $(0.191)$ & $(0.200)$ \\
\hline \multirow[t]{2}{*}{ Global health $\left({ }^{*} 10\right)^{\star}$ father's ed. } & -0.002 & & 0.007 & -0.016 & & -0.001 \\
\hline & $(0.016)$ & & $(0.018)$ & $(0.018)$ & & $(0.021)$ \\
\hline \multirow[t]{2}{*}{ Global health $\left({ }^{*} 10\right)^{*}$ mother's ed. } & & -0.012 & -0.008 & & -0.032 & -0.032 \\
\hline & & $(0.017)$ & $(0.020)$ & & $(0.020)$ & $(0.023)$ \\
\hline \multirow[t]{2}{*}{ Father's education } & $0.284^{\star \star \star}$ & & $0.193^{\star \star \star}$ & & & \\
\hline & $(0.014)$ & & $(0.015)$ & & & \\
\hline \multirow[t]{2}{*}{ Mother's education } & & $0.300^{\star \star \star}$ & $0.210^{* * *}$ & & & \\
\hline & & $(0.014)$ & $(0.015)$ & & & \\
\hline R-squared & 0.125 & 0.130 & 0.171 & 0.001 & 0.002 & 0.002 \\
\hline F-test & 0.000 *** & $0.000^{\star \star \star}$ & $0.000^{* * *}$ & 0.484 & 0.186 & 0.339 \\
\hline Twin-fixed effects & NO & NO & NO & YES & YES & YES \\
\hline Observations & \multicolumn{6}{|c|}{3,748} \\
\hline
\end{tabular}

Notes: Standard errors in parentheses. * indicates $10 \%$ significance, ** $5 \%$ significance, and $* * * 1 \%$ significance. "F-test" is the p-value from an F-test based on the null hypothesis that all health coefficients (including the interactions) equal zero. 
Table A3.2: Health conditions and educational attainment. Interactions with parental educational attainment

\begin{tabular}{|c|c|c|c|c|c|c|}
\hline VARIABLES & $A$ & B & C & D & $E$ & $F$ \\
\hline Mental & $\begin{array}{c}-1.440^{\star * *} \\
(0.239)\end{array}$ & $\begin{array}{c}-1.190^{\star \star \star} \\
(0.271)\end{array}$ & $\begin{array}{c}-1.213^{\star \star *} \\
(0.268)\end{array}$ & $\begin{array}{l}-0.015 \\
(0.255)\end{array}$ & $\begin{array}{c}0.246 \\
(0.307)\end{array}$ & $\begin{array}{c}0.219 \\
(0.314)\end{array}$ \\
\hline Circulatory & $\begin{array}{l}-0.356 \\
(0.319)\end{array}$ & $\begin{array}{l}-0.184 \\
(0.352)\end{array}$ & $\begin{array}{l}-0.223 \\
(0.356)\end{array}$ & $\begin{array}{c}0.056 \\
(0.272)\end{array}$ & $\begin{array}{l}-0.006 \\
(0.306)\end{array}$ & $\begin{array}{l}-0.034 \\
(0.314)\end{array}$ \\
\hline Musculoskeletal & $\begin{array}{l}-0.174 \\
(0.182)\end{array}$ & $\begin{array}{l}-0.158 \\
(0.208)\end{array}$ & $\begin{array}{l}-0.217 \\
(0.213)\end{array}$ & $\begin{array}{l}0.387^{\star *} \\
(0.153)\end{array}$ & $\begin{array}{l}0.307^{*} \\
(0.168)\end{array}$ & $\begin{array}{l}0.399 * * \\
(0.176)\end{array}$ \\
\hline Digestive & $\begin{array}{l}-0.388 \\
(0.324)\end{array}$ & $\begin{array}{l}-0.377 \\
(0.397)\end{array}$ & $\begin{array}{l}-0.348 \\
(0.390)\end{array}$ & $\begin{array}{l}-0.553^{*} \\
(0.283)\end{array}$ & $\begin{array}{l}-0.536 \\
(0.336)\end{array}$ & $\begin{array}{l}-0.566^{*} \\
(0.337)\end{array}$ \\
\hline Skin & $\begin{array}{c}0.379 \\
(0.291)\end{array}$ & $\begin{array}{c}0.286 \\
(0.355)\end{array}$ & $\begin{array}{c}0.283 \\
(0.361)\end{array}$ & $\begin{array}{c}-0.704^{\star *} \\
(0.297)\end{array}$ & $\begin{array}{l}-0.316 \\
(0.368)\end{array}$ & $\begin{array}{l}-0.519 \\
(0.382)\end{array}$ \\
\hline Respiratory & $\begin{array}{c}0.321 \\
(0.247)\end{array}$ & $\begin{array}{c}0.327 \\
(0.311)\end{array}$ & $\begin{array}{c}0.289 \\
(0.314)\end{array}$ & $\begin{array}{c}0.180 \\
(0.261)\end{array}$ & $\begin{array}{l}0.642^{\star} \\
(0.343)\end{array}$ & $\begin{array}{l}0.707^{\star *} \\
(0.356)\end{array}$ \\
\hline Injuries and poisonings & $\begin{array}{l}-0.090 \\
(0.305)\end{array}$ & $\begin{array}{l}-0.019 \\
(0.362)\end{array}$ & $\begin{array}{l}-0.064 \\
(0.369)\end{array}$ & $\begin{array}{c}0.010 \\
(0.247)\end{array}$ & $\begin{array}{c}0.113 \\
(0.294)\end{array}$ & $\begin{array}{c}0.114 \\
(0.309)\end{array}$ \\
\hline Mental*father’s ed. & $\begin{array}{c}0.041 \\
(0.037)\end{array}$ & & $\begin{array}{l}0.089^{* *} \\
(0.044)\end{array}$ & $\begin{array}{l}-0.001 \\
(0.038)\end{array}$ & & $\begin{array}{c}0.027 \\
(0.042)\end{array}$ \\
\hline Circulatory^father's ed. & $\begin{array}{c}0.040 \\
(0.038)\end{array}$ & & $\begin{array}{c}0.049 \\
(0.046)\end{array}$ & $\begin{array}{c}0.010 \\
(0.032)\end{array}$ & & $\begin{array}{c}0.001 \\
(0.041)\end{array}$ \\
\hline Musculoskeletalfather's ed. & $\begin{array}{l}-0.004 \\
(0.021)\end{array}$ & & $\begin{array}{c}0.003 \\
(0.024)\end{array}$ & $\begin{array}{l}-0.041^{* *} \\
(0.017)\end{array}$ & & $\begin{array}{l}-0.036^{*} \\
(0.021)\end{array}$ \\
\hline Digestive*father's ed. & $\begin{array}{c}0.036 \\
(0.037)\end{array}$ & & $\begin{array}{c}0.056 \\
(0.047)\end{array}$ & $\begin{array}{c}0.035 \\
(0.031)\end{array}$ & & $\begin{array}{c}0.032 \\
(0.044)\end{array}$ \\
\hline Skin*father's ed. & $\begin{array}{l}-0.048 \\
(0.030)\end{array}$ & & $\begin{array}{l}-0.038 \\
(0.034)\end{array}$ & $\begin{array}{c}0.044 \\
(0.030)\end{array}$ & & $\begin{array}{l}0.062^{*} \\
(0.035)\end{array}$ \\
\hline Respiratory*father's ed. & $\begin{array}{c}0.002 \\
(0.024)\end{array}$ & & $\begin{array}{c}0.003 \\
(0.027)\end{array}$ & $\begin{array}{l}-0.026 \\
(0.025)\end{array}$ & & $\begin{array}{c}0.002 \\
(0.028)\end{array}$ \\
\hline Injuries^father’s ed. & $\begin{array}{c}0.018 \\
(0.031)\end{array}$ & & $\begin{array}{c}0.010 \\
(0.036)\end{array}$ & $\begin{array}{l}-0.003 \\
(0.025)\end{array}$ & & $\begin{array}{c}0.001 \\
(0.029)\end{array}$ \\
\hline Mentalmother's ed. & & $\begin{array}{c}-0.012 \\
(0.036)\end{array}$ & $\begin{array}{c}-0.063 \\
(0.043)\end{array}$ & & $\begin{array}{c}-0.043 \\
(0.037)\end{array}$ & $\begin{array}{l}-0.057 \\
(0.042)\end{array}$ \\
\hline Circulatory*mother's ed. & & $\begin{array}{c}0.015 \\
(0.039)\end{array}$ & $\begin{array}{l}-0.019 \\
(0.048)\end{array}$ & & $\begin{array}{c}0.017 \\
(0.034)\end{array}$ & $\begin{array}{c}0.019 \\
(0.043)\end{array}$ \\
\hline Musculoskeletalmother's ed. & & $\begin{array}{l}-0.007 \\
(0.022)\end{array}$ & $\begin{array}{c}0.002 \\
(0.025)\end{array}$ & & $\begin{array}{l}-0.028 \\
(0.018)\end{array}$ & $\begin{array}{l}-0.007 \\
(0.022)\end{array}$ \\
\hline Digestive*mother's ed. & & $\begin{array}{c}0.018 \\
(0.040)\end{array}$ & $\begin{array}{l}-0.026 \\
(0.051)\end{array}$ & & $\begin{array}{c}0.029 \\
(0.034)\end{array}$ & $\begin{array}{c}0.004 \\
(0.048)\end{array}$ \\
\hline Skin*mother's ed. & & $\begin{array}{l}-0.039 \\
(0.034)\end{array}$ & $\begin{array}{l}-0.004 \\
(0.038)\end{array}$ & & $\begin{array}{l}-0.002 \\
(0.034)\end{array}$ & $\begin{array}{l}-0.035 \\
(0.040)\end{array}$ \\
\hline Respiratory*mother's ed. & & $\begin{array}{c}0.000 \\
(0.028)\end{array}$ & $\begin{array}{l}-0.004 \\
(0.032)\end{array}$ & & $\begin{array}{l}-0.071^{* *} \\
(0.031)\end{array}$ & $\begin{array}{c}-0.076^{\star *} \\
(0.035)\end{array}$ \\
\hline Injuries*mother's ed. & & $\begin{array}{c}0.003 \\
(0.034)\end{array}$ & $\begin{array}{l}-0.001 \\
(0.039)\end{array}$ & & $\begin{array}{l}-0.013 \\
(0.028)\end{array}$ & $\begin{array}{l}-0.013 \\
(0.032)\end{array}$ \\
\hline Father's educational attainment & $\begin{array}{c}0.279 * \star \star \\
(0.014)\end{array}$ & & $\begin{array}{c}0.190 * * * \\
(0.015)\end{array}$ & & & \\
\hline Mother's educational attainment & & $\begin{array}{c}0.293^{\star \star *} \\
(0.014) \\
\end{array}$ & $\begin{array}{c}0.208^{\star \star \star} \\
(0.016) \\
\end{array}$ & & & \\
\hline R-squared & 0.135 & 0.139 & 0.179 & 0.010 & 0.011 & 0.015 \\
\hline F-test & $0.000 * \star \star$ & 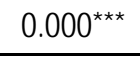 & $0.000^{\star \star \star}$ & 0.165 & 0.129 & 0.159 \\
\hline Twin-fixed effects & NO & NO & NO & YES & YES & YES \\
\hline
\end{tabular}


Observations

3,748

Notes: Standard errors in parentheses. * indicates $10 \%$ significance, $* * 5 \%$ significance, and $* * * 1 \%$ significance. "F-test" is the p-value from an F-test based on the null hypothesis that all health coefficients (including the interactions) equal zero. 
Table A3.3: Physical test variables and educational attainment. Interactions with parental educational attainment

\begin{tabular}{|c|c|c|c|c|c|c|}
\hline VARIABLES & A & $B$ & $\mathrm{C}$ & $\mathrm{D}$ & $E$ & $\mathrm{~F}$ \\
\hline Low physical capacity & $\begin{array}{c}-0.690^{\star *} \\
(0.280)\end{array}$ & $\begin{array}{c}-0.712^{\star *} \\
(0.332)\end{array}$ & $\begin{array}{l}-0.537 \\
(0.340)\end{array}$ & $\begin{array}{l}-0.290 \\
(0.291)\end{array}$ & $\begin{array}{l}-0.515 \\
(0.374)\end{array}$ & $\begin{array}{l}-0.569 \\
(0.385)\end{array}$ \\
\hline Weak handgrip strength & $\begin{array}{c}0.236 \\
(0.289)\end{array}$ & $\begin{array}{c}0.055 \\
(0.357)\end{array}$ & $\begin{array}{c}0.224 \\
(0.357)\end{array}$ & $\begin{array}{l}-0.011 \\
(0.279)\end{array}$ & $\begin{array}{c}0.223 \\
(0.348)\end{array}$ & $\begin{array}{c}0.196 \\
(0.354)\end{array}$ \\
\hline Hypertension & $\begin{array}{l}-0.052 \\
(0.144)\end{array}$ & $\begin{array}{l}-0.213 \\
(0.176)\end{array}$ & $\begin{array}{l}-0.168 \\
(0.175)\end{array}$ & $\begin{array}{c}0.171 \\
(0.134)\end{array}$ & $\begin{array}{c}0.185 \\
(0.167)\end{array}$ & $\begin{array}{c}0.222 \\
(0.171)\end{array}$ \\
\hline Overweight & $\begin{array}{c}-0.690^{\star *} \\
(0.293)\end{array}$ & $\begin{array}{l}-0.660^{*} \\
(0.370)\end{array}$ & $\begin{array}{l}-0.607 \\
(0.370)\end{array}$ & $\begin{array}{c}0.186 \\
(0.305)\end{array}$ & $\begin{array}{l}-0.362 \\
(0.368)\end{array}$ & $\begin{array}{l}-0.190 \\
(0.382)\end{array}$ \\
\hline Short & $\begin{array}{c}-0.849^{* \star *} \\
(0.295)\end{array}$ & $\begin{array}{l}-0.610^{*} \\
(0.331)\end{array}$ & $\begin{array}{c}-0.811^{\text {* }} \\
(0.347)\end{array}$ & $\begin{array}{l}-0.360 \\
(0.427)\end{array}$ & $\begin{array}{l}-0.455 \\
(0.510)\end{array}$ & $\begin{array}{l}-0.466 \\
(0.515)\end{array}$ \\
\hline Low visual aquity & $\begin{array}{l}-0.330 \\
(0.253)\end{array}$ & $\begin{array}{l}-0.360 \\
(0.329)\end{array}$ & $\begin{array}{l}-0.418 \\
(0.328)\end{array}$ & $\begin{array}{l}-0.216 \\
(0.266)\end{array}$ & $\begin{array}{l}-0.504 \\
(0.312)\end{array}$ & $\begin{array}{l}-0.487 \\
(0.326)\end{array}$ \\
\hline Low hearing acuity & $\begin{array}{l}-0.166 \\
(0.241)\end{array}$ & $\begin{array}{l}-0.298 \\
(0.278)\end{array}$ & $\begin{array}{l}-0.237 \\
(0.277)\end{array}$ & $\begin{array}{l}-0.142 \\
(0.222)\end{array}$ & $\begin{array}{l}-0.021 \\
(0.263)\end{array}$ & $\begin{array}{l}-0.040 \\
(0.269)\end{array}$ \\
\hline Low physical capacity^father’s ed. & $\begin{array}{l}-0.039 \\
(0.034)\end{array}$ & & $\begin{array}{l}-0.035 \\
(0.037)\end{array}$ & $\begin{array}{c}0.037 \\
(0.033)\end{array}$ & & $\begin{array}{c}0.013 \\
(0.038)\end{array}$ \\
\hline Weak handgrip^father's ed. & $\begin{array}{l}-0.003 \\
(0.034)\end{array}$ & & $\begin{array}{l}-0.022 \\
(0.040)\end{array}$ & $\begin{array}{c}0.001 \\
(0.032)\end{array}$ & & $\begin{array}{c}0.026 \\
(0.040)\end{array}$ \\
\hline Hypertension*father's ed. & $\begin{array}{c}0.009 \\
(0.016)\end{array}$ & & $\begin{array}{l}-0.001 \\
(0.019)\end{array}$ & $\begin{array}{l}-0.006 \\
(0.015)\end{array}$ & & $\begin{array}{l}-0.001 \\
(0.018)\end{array}$ \\
\hline Overweightfather's ed. & $\begin{array}{c}0.022 \\
(0.032)\end{array}$ & & $\begin{array}{c}0.026 \\
(0.037)\end{array}$ & $\begin{array}{l}-0.035 \\
(0.034)\end{array}$ & & $\begin{array}{l}-0.069 * \\
(0.040)\end{array}$ \\
\hline Shortfather's ed. & $\begin{array}{l}0.065^{*} \\
(0.035)\end{array}$ & & $\begin{array}{c}0.062 \\
(0.039)\end{array}$ & $\begin{array}{c}0.001 \\
(0.049)\end{array}$ & & $\begin{array}{l}-0.014 \\
(0.065)\end{array}$ \\
\hline Low visual aquity*father's ed. & $\begin{array}{c}0.014 \\
(0.030)\end{array}$ & & $\begin{array}{c}0.006 \\
(0.034)\end{array}$ & $\begin{array}{c}0.021 \\
(0.029)\end{array}$ & & $\begin{array}{l}-0.000 \\
(0.035)\end{array}$ \\
\hline Low hearing acuity^father's ed. & $\begin{array}{l}-0.019 \\
(0.029)\end{array}$ & & $\begin{array}{l}-0.021 \\
(0.036)\end{array}$ & $\begin{array}{c}0.002 \\
(0.026)\end{array}$ & & $\begin{array}{c}0.012 \\
(0.031)\end{array}$ \\
\hline Low physical capacitymother's ed. & & $\begin{array}{l}-0.025 \\
(0.037)\end{array}$ & $\begin{array}{l}-0.013 \\
(0.040)\end{array}$ & & $\begin{array}{c}0.058 \\
(0.039)\end{array}$ & $\begin{array}{c}0.053 \\
(0.045)\end{array}$ \\
\hline Weak handgrip*mother's ed. & & $\begin{array}{c}0.017 \\
(0.038)\end{array}$ & $\begin{array}{c}0.018 \\
(0.044)\end{array}$ & & $\begin{array}{l}-0.028 \\
(0.036)\end{array}$ & $\begin{array}{l}-0.046 \\
(0.045)\end{array}$ \\
\hline Hypertension*mother's ed. & & $\begin{array}{c}0.028 \\
(0.018)\end{array}$ & $\begin{array}{c}0.024 \\
(0.021)\end{array}$ & & $\begin{array}{l}-0.006 \\
(0.016)\end{array}$ & $\begin{array}{l}-0.008 \\
(0.020)\end{array}$ \\
\hline Overweight*mother's ed. & & $\begin{array}{c}0.006 \\
(0.036)\end{array}$ & $\begin{array}{l}-0.012 \\
(0.042)\end{array}$ & & $\begin{array}{c}0.033 \\
(0.036)\end{array}$ & $\begin{array}{l}0.071^{*} \\
(0.043)\end{array}$ \\
\hline Short*mother's ed. & & $\begin{array}{c}0.015 \\
(0.035)\end{array}$ & $\begin{array}{l}-0.000 \\
(0.038)\end{array}$ & & $\begin{array}{c}0.014 \\
(0.053)\end{array}$ & $\begin{array}{c}0.027 \\
(0.071)\end{array}$ \\
\hline Low visual aquity*mother's ed. & & $\begin{array}{c}0.015 \\
(0.034)\end{array}$ & $\begin{array}{c}0.021 \\
(0.039)\end{array}$ & & $\begin{array}{c}0.053 \\
(0.032)\end{array}$ & $\begin{array}{c}0.052 \\
(0.039)\end{array}$ \\
\hline Low hearing aquity*mother's ed. & & $\begin{array}{l}-0.004 \\
(0.030)\end{array}$ & $\begin{array}{c}0.012 \\
(0.038)\end{array}$ & & $\begin{array}{l}-0.013 \\
(0.027)\end{array}$ & $\begin{array}{l}-0.021 \\
(0.033)\end{array}$ \\
\hline Father's education & $\begin{array}{c}0.268^{* * *} \\
(0.014)\end{array}$ & & $\begin{array}{c}0.189^{\star \star \star} \\
(0.015)\end{array}$ & & & \\
\hline Mother's education & & $\begin{array}{l}0.274^{\star * *} \\
(0.014) \\
\end{array}$ & $\begin{array}{c}0.190^{\star * *} \\
(0.016) \\
\end{array}$ & & & \\
\hline R-squared & 0.146 & 0.148 & 0.189 & 0.008 & 0.011 & 0.013 \\
\hline F-tests & $0.000^{\star * *}$ & $0.000^{\star \star *}$ & $0.000^{* \star *}$ & 0.864 & 0.602 & 0.763 \\
\hline Twin-fixed effects & NO & NO & NO & YES & YES & YES \\
\hline
\end{tabular}


Observations

3,748

Notes: Standard errors in parentheses. * indicates $10 \%$ significance, ${ }^{* *} 5 \%$ significance, and ${ }^{* * *} 1 \%$ significance. "F-test" is the p-value from an F-test based on the null hypothesis that all health coefficients (including the interactions) equal zero. 


\section{Appendix 4: Interactions with cognitive and noncognitive ability}

Table A4.1: Global health and educational attainment. Interactions with cognitive and noncognitive ability

\begin{tabular}{|c|c|c|c|c|c|c|}
\hline VARIABLES & $A$ & B & C & D & $E$ & $\mathrm{~F}$ \\
\hline \multirow[t]{2}{*}{ Global health $\left({ }^{\star} 10\right)$} & 0.008 & $0.187^{\star}$ & $0.194^{*}$ & -0.108 & -0.026 & -0.057 \\
\hline & $(0.085)$ & $(0.113)$ & $(0.100)$ & $(0.098)$ & $(0.110)$ & $(0.110)$ \\
\hline \multirow[t]{2}{*}{ Global health $\left({ }^{*} 10\right)^{\star}{ }^{\star}$ cog. ability } & $-0.212^{\star \star \star}$ & & -0.250 *** & 0.034 & & 0.019 \\
\hline & $(0.081)$ & & $(0.088)$ & $(0.088)$ & & $(0.095)$ \\
\hline \multirow[t]{2}{*}{ Global health(*10)*noncog. ability } & & 0.003 & 0.018 & & 0.005 & 0.033 \\
\hline & & $(0.089)$ & $(0.086)$ & & $(0.009)$ & $(0.095)$ \\
\hline \multirow[t]{2}{*}{ Cognitive ability } & $1.331^{\star \star \star}$ & & $1.233^{\star \star \star}$ & $0.407^{\star \star \star}$ & & $0.387^{\star \star \star}$ \\
\hline & $(0.039)$ & & $(0.042)$ & $(0.069)$ & & $(0.070)$ \\
\hline \multirow[t]{2}{*}{ Noncognitive ability } & & $0.767^{\star \star \star}$ & $0.299 * * *$ & & $0.162^{\star \star \star}$ & $0.113^{*}$ \\
\hline & & $(0.046)$ & $(0.044)$ & & $(0.057)$ & $(0.058)$ \\
\hline R-squared & 0.285 & 0.096 & 0.297 & 0.024 & 0.008 & 0.028 \\
\hline F-test & $0.028^{\star \star}$ & 0.195 & $0.002^{\star \star \star}$ & 0.483 & 0.730 & 0.849 \\
\hline Twin-fixed effects & NO & NO & NO & YES & YES & YES \\
\hline Observations & \multicolumn{6}{|c|}{3,748} \\
\hline
\end{tabular}

Notes: Standard errors in parentheses. * indicates $10 \%$ significance, ** $5 \%$ significance, and *** $1 \%$ significance. "F-test" is the p-value from an F-test based on the null hypothesis that all health coefficients (including the interactions) equal zero. 
Table A4.2: Health conditions and educational attainment. Interactions with cognitive and noncognitive ability

\begin{tabular}{|c|c|c|c|c|c|c|}
\hline VARIABLES & A & $\mathrm{B}$ & $\mathrm{C}$ & $\mathrm{D}$ & $E$ & $\mathrm{~F}$ \\
\hline Mental & $\begin{array}{c}-0.946^{\star \star \star} \\
(0.191)\end{array}$ & $\begin{array}{c}-1.260^{\star \star *} \\
(0.325)\end{array}$ & $\begin{array}{c}-0.931^{\star \star *} \\
(0.293)\end{array}$ & $\begin{array}{c}0.065 \\
(0.199)\end{array}$ & $\begin{array}{c}0.282 \\
(0.303)\end{array}$ & $\begin{array}{c}0.252 \\
(0.301)\end{array}$ \\
\hline Circulatory & $\begin{array}{c}0.111 \\
(0.184)\end{array}$ & $\begin{array}{l}-0.151 \\
(0.204)\end{array}$ & $\begin{array}{c}0.122 \\
(0.183)\end{array}$ & $\begin{array}{c}0.140 \\
(0.175)\end{array}$ & $\begin{array}{c}0.144 \\
(0.175)\end{array}$ & $\begin{array}{c}0.171 \\
(0.176)\end{array}$ \\
\hline Musculoskeletal & $\begin{array}{l}-0.126 \\
(0.100)\end{array}$ & $\begin{array}{l}-0.115 \\
(0.113)\end{array}$ & $\begin{array}{l}-0.085 \\
(0.100)\end{array}$ & $\begin{array}{c}0.113 \\
(0.093)\end{array}$ & $\begin{array}{c}0.103 \\
(0.094)\end{array}$ & $\begin{array}{c}0.106 \\
(0.093)\end{array}$ \\
\hline Digestive & $\begin{array}{l}-0.029 \\
(0.185)\end{array}$ & $\begin{array}{c}0.062 \\
(0.216)\end{array}$ & $\begin{array}{c}0.068 \\
(0.192)\end{array}$ & $\begin{array}{l}-0.268 \\
(0.177)\end{array}$ & $\begin{array}{l}-0.233 \\
(0.193)\end{array}$ & $\begin{array}{l}-0.204 \\
(0.191)\end{array}$ \\
\hline Skin & $\begin{array}{l}0.257^{\star} \\
(0.148)\end{array}$ & $\begin{array}{c}0.198 \\
(0.166)\end{array}$ & $\begin{array}{l}0.304^{* *} \\
(0.147)\end{array}$ & $\begin{array}{l}-0.280^{*} \\
(0.156)\end{array}$ & $\begin{array}{l}-0.301^{*} \\
(0.158)\end{array}$ & $\begin{array}{l}-0.264^{*} \\
(0.157)\end{array}$ \\
\hline Respiratory & $\begin{array}{c}0.315^{\star \star *} \\
(0.117)\end{array}$ & $\begin{array}{c}0.529 \star \star \star \\
(0.129)\end{array}$ & $\begin{array}{c}0.345^{\star \star \star} \\
(0.116)\end{array}$ & $\begin{array}{l}-0.091 \\
(0.126)\end{array}$ & $\begin{array}{l}-0.041 \\
(0.127)\end{array}$ & $\begin{array}{l}-0.048 \\
(0.126)\end{array}$ \\
\hline Injuries and poisonings & $\begin{array}{c}0.220 \\
(0.148)\end{array}$ & $\begin{array}{c}0.270 \\
(0.167)\end{array}$ & $\begin{array}{l}0.255^{\star} \\
(0.148)\end{array}$ & $\begin{array}{l}-0.032 \\
(0.134)\end{array}$ & $\begin{array}{l}-0.013 \\
(0.135)\end{array}$ & $\begin{array}{l}-0.029 \\
(0.135)\end{array}$ \\
\hline Mental*cog. ability & $\begin{array}{l}-0.419^{* *} \\
(0.169)\end{array}$ & & $\begin{array}{l}-0.334^{*} \\
(0.172)\end{array}$ & $\begin{array}{c}0.183 \\
(0.182)\end{array}$ & & $\begin{array}{c}0.147 \\
(0.186)\end{array}$ \\
\hline Circulatory*cog. ability & $\begin{array}{c}0.121 \\
(0.194)\end{array}$ & & $\begin{array}{c}0.285 \\
(0.225)\end{array}$ & $\begin{array}{l}-0.034 \\
(0.185)\end{array}$ & & $\begin{array}{c}0.134 \\
(0.217)\end{array}$ \\
\hline Musculoskeletal*og. ability & $\begin{array}{l}-0.064 \\
(0.105)\end{array}$ & & $\begin{array}{l}-0.037 \\
(0.114)\end{array}$ & $\begin{array}{c}0.137 \\
(0.096)\end{array}$ & & $\begin{array}{l}0.195^{\star} \\
(0.104)\end{array}$ \\
\hline Digestive*cog. ability & $\begin{array}{c}0.119 \\
(0.179)\end{array}$ & & $\begin{array}{c}0.037 \\
(0.193)\end{array}$ & $\begin{array}{l}-0.086 \\
(0.170)\end{array}$ & & $\begin{array}{l}-0.101 \\
(0.179)\end{array}$ \\
\hline Skin*cog. ability & $\begin{array}{l}-0.250 \\
(0.156)\end{array}$ & & $\begin{array}{c}-0.405^{* *} \\
(0.171)\end{array}$ & $\begin{array}{l}-0.381^{*} \\
(0.151)\end{array}$ & & $\begin{array}{c}-0.550^{* * *} \\
(0.170)\end{array}$ \\
\hline Respiratory ${ }^{\star} \operatorname{cog}$. ability & $\begin{array}{c}0.128 \\
(0.120)\end{array}$ & & $\begin{array}{c}0.074 \\
(0.136)\end{array}$ & $\begin{array}{c}0.067 \\
(0.129)\end{array}$ & & $\begin{array}{c}0.028 \\
(0.146)\end{array}$ \\
\hline Injuries ${ }^{*} \operatorname{cog}$. ability & $\begin{array}{l}-0.020 \\
(0.153)\end{array}$ & & $\begin{array}{l}-0.017 \\
(0.168)\end{array}$ & $\begin{array}{c}0.012 \\
(0.135)\end{array}$ & & $\begin{array}{c}0.013 \\
(0.148)\end{array}$ \\
\hline Mental*noncog. Ability & & $\begin{array}{l}-0.536^{\star *} \\
(0.226)\end{array}$ & $\begin{array}{l}-0.247 \\
(0.204)\end{array}$ & & $\begin{array}{c}0.127 \\
(0.207)\end{array}$ & $\begin{array}{c}0.096 \\
(0.210)\end{array}$ \\
\hline Circulatory*noncog. ability & & $\begin{array}{l}-0.173 \\
(0.198)\end{array}$ & $\begin{array}{l}-0.376^{*} \\
(0.204)\end{array}$ & & $\begin{array}{l}-0.325^{\star} \\
(0.171)\end{array}$ & $\begin{array}{l}-0.335^{\star} \\
(0.198)\end{array}$ \\
\hline Musculoskeletal*noncog. ability & & $\begin{array}{l}-0.050 \\
(0.121)\end{array}$ & $\begin{array}{l}-0.076 \\
(0.118)\end{array}$ & & $\begin{array}{l}-0.063 \\
(0.098)\end{array}$ & $\begin{array}{l}-0.120 \\
(0.105)\end{array}$ \\
\hline Digestive*noncog. ability & & $\begin{array}{c}0.248 \\
(0.221)\end{array}$ & $\begin{array}{c}0.221 \\
(0.212)\end{array}$ & & $\begin{array}{l}0.056 \\
(0.190)\end{array}$ & $\begin{array}{c}0.136 \\
(0.198)\end{array}$ \\
\hline Skin*noncog. ability & & $\begin{array}{c}0.189 \\
(0.172)\end{array}$ & $\begin{array}{l}0.347^{* \star} \\
(0.168)\end{array}$ & & $\begin{array}{c}0.125 \\
(0.146)\end{array}$ & $\begin{array}{l}0.365^{\star \star} \\
(0.163)\end{array}$ \\
\hline Respiratory*noncog. ability & & $\begin{array}{c}0.231 \\
(0.142)\end{array}$ & $\begin{array}{c}0.043 \\
(0.144)\end{array}$ & & $\begin{array}{c}0.045 \\
(0.126)\end{array}$ & $\begin{array}{c}0.013 \\
(0.141)\end{array}$ \\
\hline Injuries*noncog. ability & & $\begin{array}{c}0.068 \\
(0.189)\end{array}$ & $\begin{array}{c}-0.010 \\
(0.184)\end{array}$ & & $\begin{array}{c}0.015 \\
(0.150)\end{array}$ & $\begin{array}{c}0.001 \\
(0.163)\end{array}$ \\
\hline Cognitive ability & $\begin{array}{c}1.272^{\star \star \star} \\
(0.040)\end{array}$ & & $\begin{array}{c}1.187^{\star \star \star} \\
(0.043)\end{array}$ & $\begin{array}{c}0.395^{\star \star \star} \\
(0.068)\end{array}$ & & $\begin{array}{c}0.366^{\star \star \star} \\
(0.069)\end{array}$ \\
\hline Noncognitive ability & & $\begin{array}{c}0.700^{\star * *} \\
(0.045) \\
\end{array}$ & $\begin{array}{c}0.251^{* * *} \\
(0.043) \\
\end{array}$ & & $\begin{array}{l}0.184^{\star \star \star} \\
(0.057) \\
\end{array}$ & $\begin{array}{l}0.130^{* *} \\
(0.058) \\
\end{array}$ \\
\hline R-squared & 0.292 & 0.107 & 0.303 & 0.033 & 0.015 & 0.042 \\
\hline F-test & $0.000^{* \star *}$ & $0.000^{\star \star \star}$ & $0.001^{\star \star \star}$ & 0.188 & 0.421 & 0.123 \\
\hline Twin-fixed effects & NO & NO & $\mathrm{NO}$ & YES & YES & YES \\
\hline
\end{tabular}


Observations

3,748

Notes: Standard errors in parentheses. * indicates $10 \%$ significance, ${ }^{* *} 5 \%$ significance, and ${ }^{* * *} 1 \%$ significance. "F-test" is the p-value from an F-test based on the null hypothesis that all health coefficients (including the interactions) equal zero. 
Table A4.3: Physical test variables and educational attainment. Interactions with cognitive and noncognitive ability

\begin{tabular}{|c|c|c|c|c|c|c|}
\hline VARIABLES & A & $\mathrm{B}$ & $\mathrm{C}$ & $\mathrm{D}$ & $E$ & $\mathrm{~F}$ \\
\hline Low physical capacity & $\begin{array}{c}-0.663^{\star \star \star} \\
(0.168)\end{array}$ & $\begin{array}{c}-0.689 * * * \\
(0.243)\end{array}$ & $\begin{array}{c}-0.855^{\star \star \star} \\
(0.216)\end{array}$ & $\begin{array}{l}-0.067 \\
(0.191)\end{array}$ & $\begin{array}{l}-0.320 \\
(0.230)\end{array}$ & $\begin{array}{l}-0.354 \\
(0.231)\end{array}$ \\
\hline Weak handgrip strength & $\begin{array}{c}0.441^{\star * \star} \\
(0.169)\end{array}$ & $\begin{array}{c}0.290 \\
(0.196)\end{array}$ & $\begin{array}{c}0.456^{\star * *} \\
(0.175)\end{array}$ & $\begin{array}{c}0.061 \\
(0.177)\end{array}$ & $\begin{array}{l}-0.027 \\
(0.183)\end{array}$ & $\begin{array}{c}0.014 \\
(0.182)\end{array}$ \\
\hline Hypertension & $\begin{array}{c}0.032 \\
(0.079)\end{array}$ & $\begin{array}{l}-0.011 \\
(0.089)\end{array}$ & $\begin{array}{c}0.028 \\
(0.079)\end{array}$ & $\begin{array}{l}0.140^{*} \\
(0.082)\end{array}$ & $\begin{array}{l}0.147^{*} \\
(0.083)\end{array}$ & $\begin{array}{c}0.151^{*} \\
(0.082)\end{array}$ \\
\hline Overweight & $\begin{array}{c}-0.415^{\star \star \star} \\
(0.146)\end{array}$ & $\begin{array}{c}-0.534^{\star * *} \\
(0.163)\end{array}$ & $\begin{array}{c}-0.389^{\star \star \star} \\
(0.145)\end{array}$ & $\begin{array}{l}-0.043 \\
(0.178)\end{array}$ & $\begin{array}{l}-0.042 \\
(0.179)\end{array}$ & $\begin{array}{l}-0.044 \\
(0.180)\end{array}$ \\
\hline Short & $\begin{array}{l}-0.141 \\
(0.160)\end{array}$ & $\begin{array}{c}-0.451^{\star \star} \\
(0.176)\end{array}$ & $\begin{array}{l}-0.107 \\
(0.159)\end{array}$ & $\begin{array}{l}-0.273 \\
(0.261)\end{array}$ & $\begin{array}{l}-0.346 \\
(0.262)\end{array}$ & $\begin{array}{c}-0.266 \\
(0.261)\end{array}$ \\
\hline Low visual aquity & $\begin{array}{l}-0.154 \\
(0.146)\end{array}$ & $\begin{array}{l}-0.244 \\
(0.164)\end{array}$ & $\begin{array}{l}-0.105 \\
(0.146)\end{array}$ & $\begin{array}{l}-0.005 \\
(0.155)\end{array}$ & $\begin{array}{l}-0.071 \\
(0.156)\end{array}$ & $\begin{array}{l}-0.008 \\
(0.156)\end{array}$ \\
\hline Low hearing acuity & $\begin{array}{l}-0.253^{*} \\
(0.142)\end{array}$ & $\begin{array}{l}-0.327^{\star *} \\
(0.159)\end{array}$ & $\begin{array}{l}-0.243^{\star} \\
(0.141)\end{array}$ & $\begin{array}{l}-0.143 \\
(0.140)\end{array}$ & $\begin{array}{l}-0.148 \\
(0.142)\end{array}$ & $\begin{array}{l}-0.149 \\
(0.142)\end{array}$ \\
\hline Low physical capacitycog. & $\begin{array}{l}-0.273^{\star} \\
(0.140)\end{array}$ & & $\begin{array}{l}-0.044 \\
(0.158)\end{array}$ & $\begin{array}{c}-0.241 \\
(0.164)\end{array}$ & & $\begin{array}{l}-0.119 \\
(0.169)\end{array}$ \\
\hline Weak handgripcog. & $\begin{array}{l}-0.014 \\
(0.156)\end{array}$ & & $\begin{array}{c}0.095 \\
(0.164)\end{array}$ & $\begin{array}{c}0.226 \\
(0.153)\end{array}$ & & $\begin{array}{c}0.284^{*} \\
(0.163)\end{array}$ \\
\hline Hypertension*cog. & $\begin{array}{l}-0.034 \\
(0.082)\end{array}$ & & $\begin{array}{c}-0.031 \\
(0.089)\end{array}$ & $\begin{array}{c}-0.118 \\
(0.083)\end{array}$ & & $\begin{array}{l}-0.100 \\
(0.089)\end{array}$ \\
\hline Overweight*cog. & $\begin{array}{l}-0.281^{*} \\
(0.152)\end{array}$ & & $\begin{array}{c}-0.359 * * \\
(0.168)\end{array}$ & $\begin{array}{c}-0.140 \\
(0.169)\end{array}$ & & $\begin{array}{c}-0.230 \\
(0.184)\end{array}$ \\
\hline Short*cog. & $\begin{array}{c}0.067 \\
(0.168)\end{array}$ & & $\begin{array}{c}0.093 \\
(0.184)\end{array}$ & $\begin{array}{l}-0.016 \\
(0.218)\end{array}$ & & $\begin{array}{c}0.027 \\
(0.234)\end{array}$ \\
\hline Low visual aquity*cog. & $\begin{array}{l}-0.022 \\
(0.151)\end{array}$ & & $\begin{array}{c}-0.042 \\
(0.163)\end{array}$ & $\begin{array}{l}-0.053 \\
(0.160)\end{array}$ & & $\begin{array}{l}-0.005 \\
(0.173)\end{array}$ \\
\hline Low hearing acuity*cog. & $\begin{array}{l}-0.279^{\star} \\
(0.143)\end{array}$ & & $\begin{array}{c}-0.358^{\star \star} \\
(0.158)\end{array}$ & $\begin{array}{c}0.023 \\
(0.138)\end{array}$ & & $\begin{array}{l}-0.024 \\
(0.149)\end{array}$ \\
\hline Low physical capacity*noncog. & & $\begin{array}{l}-0.297 \\
(0.205)\end{array}$ & $\begin{array}{c}-0.611^{\star * *} \\
(0.207)\end{array}$ & & $\begin{array}{c}-0.444^{\star *} \\
(0.205)\end{array}$ & $\begin{array}{c}-0.489^{* *} \\
(0.210)\end{array}$ \\
\hline Weak handgrip*noncog. & & $\begin{array}{l}-0.249 \\
(0.189)\end{array}$ & $\begin{array}{l}-0.197 \\
(0.178)\end{array}$ & & $\begin{array}{l}-0.071 \\
(0.164)\end{array}$ & $\begin{array}{l}-0.172 \\
(0.173)\end{array}$ \\
\hline Hypertension*noncog. & & $\begin{array}{l}-0.042 \\
(0.093)\end{array}$ & $\begin{array}{l}-0.015 \\
(0.089)\end{array}$ & & $\begin{array}{l}-0.079 \\
(0.085)\end{array}$ & $\begin{array}{l}-0.048 \\
(0.091)\end{array}$ \\
\hline Overweightnoncog. & & $\begin{array}{c}0.054 \\
(0.177)\end{array}$ & $\begin{array}{c}0.140 \\
(0.174)\end{array}$ & & $\begin{array}{c}0.071 \\
(0.156)\end{array}$ & $\begin{array}{c}0.152 \\
(0.168)\end{array}$ \\
\hline Short*noncog. & & $\begin{array}{c}0.067 \\
(0.191)\end{array}$ & $\begin{array}{c}0.003 \\
(0.186)\end{array}$ & & $\begin{array}{l}-0.229 \\
(0.222)\end{array}$ & $\begin{array}{l}-0.234 \\
(0.235)\end{array}$ \\
\hline Low visual aquity*noncog. & & $\begin{array}{c}0.105 \\
(0.174)\end{array}$ & $\begin{array}{c}0.139 \\
(0.168)\end{array}$ & & $\begin{array}{l}-0.063 \\
(0.151)\end{array}$ & $\begin{array}{l}-0.068 \\
(0.162)\end{array}$ \\
\hline Low hearing aquity*noncog. & & $\begin{array}{c}0.034 \\
(0.158)\end{array}$ & $\begin{array}{c}0.159 \\
(0.157)\end{array}$ & & $\begin{array}{c}0.055 \\
(0.140)\end{array}$ & $\begin{array}{c}0.058 \\
(0.152)\end{array}$ \\
\hline Cognitive ability & $\begin{array}{c}1.300^{\star \star \star} \\
(0.041)\end{array}$ & & $\begin{array}{c}1.191^{\star * *} \\
(0.044)\end{array}$ & $\begin{array}{c}0.448^{\star \star \star} \\
(0.070)\end{array}$ & & $\begin{array}{c}0.423^{\star \star \star} \\
(0.071)\end{array}$ \\
\hline Noncognitive ability & & $\begin{array}{c}0.739 * * * \\
(0.046) \\
\end{array}$ & $\begin{array}{c}0.284^{\star * *} \\
(0.044) \\
\end{array}$ & & $\begin{array}{c}0.223^{\star \star \star} \\
(0.057) \\
\end{array}$ & $\begin{array}{l}0.168^{\star \star \star} \\
(0.058)\end{array}$ \\
\hline R-squared & 0.309 & 0.132 & 0.325 & 0.034 & 0.018 & 0.043 \\
\hline F-tests & $0.000 * * \star$ & 0.000 *** & $0.000^{* * *}$ & 0.624 & 0.478 & 0.419 \\
\hline Twin-fixed effects & NO & NO & NO & YES & YES & YES \\
\hline
\end{tabular}


Observations

Notes: Standard errors in parentheses. * indicates $10 \%$ significance, ** $5 \%$ significance, and *** $1 \%$ significance. "F-test" is the p-value from an F-test based on the null hypothesis that all health coefficients (including the interactions) equal zero. 


\section{Appendix 5: Cohort specific effects}

Table A5.1: Global health and educational attainment with cohort effects

\begin{tabular}{|c|c|c|c|c|c|c|}
\hline VARIABLES & A & B & C & D & $\mathrm{E}$ & $\mathrm{F}$ \\
\hline \multirow[t]{2}{*}{ Global health*born 1950-59(*10) } & $-0.551^{\star \star *}$ & 0.036 & $0.251^{*}$ & 0.126 & 0.114 & 0.118 \\
\hline & $(0.158)$ & $(0.139)$ & $(0.146)$ & $(0.161)$ & $(0.0161)$ & $(0.164)$ \\
\hline \multirow[t]{2}{*}{ Global health*born 1960-69(*10) } & $-0.370^{\star}$ & 0.015 & 0.173 & $-0.400^{*}$ & $-0.403^{\star}$ & -0.341 \\
\hline & $(0.216)$ & $(0.192)$ & $(0.195)$ & $(0.228)$ & $(0.232)$ & $(0.233)$ \\
\hline \multirow[t]{2}{*}{ Global health*born 1970-79(*10) } & $-0.757^{\star \star \star}$ & -0.201 & 0.082 & -0.110 & -0.183 & -0.152 \\
\hline & $(0.131)$ & $(0.122)$ & $(0.143)$ & $(0.136)$ & $(0.145)$ & $(0.158)$ \\
\hline \multirow[t]{2}{*}{ Cognitive ability*born 1950-59 } & & $1.369^{\star \star *}$ & $1.275^{\star \star \star}$ & & $0.358^{\star * *}$ & $0.358^{\star * \star}$ \\
\hline & & $(0.056)$ & $(0.060)$ & & $(0.104)$ & $(0.105)$ \\
\hline \multirow[t]{2}{*}{ Cognitive ability*born 1960-69 } & & $1.163^{\star \star *}$ & $1.028^{\star \star *}$ & & $0.531^{\star \star *}$ & $0.454^{\star \star \star}$ \\
\hline & & $(0.063)$ & $(0.070)$ & & $(0.122)$ & $(0.126)$ \\
\hline \multirow[t]{2}{*}{ Cognitive ability*born 1970-79 } & & $1.221^{\star \star \star}$ & $1.133^{\star \star \star}$ & & $0.391^{\star \star \star}$ & $0.376^{\star \star \star}$ \\
\hline & & $(0.0518)$ & $(0.055)$ & & $(0.1103)$ & $(0.111)$ \\
\hline \multirow[t]{2}{*}{ Noncognitive ability*born 1950-59 } & & & $0.272^{\star \star \star}$ & & & 0.013 \\
\hline & & & $(0.060)$ & & & $(0.080)$ \\
\hline \multirow[t]{2}{*}{ Noncognitive ability*born 1960-69 } & & & $0.359^{\star \star \star}$ & & & $0.254^{* *}$ \\
\hline & & & $(0.073)$ & & & $(0.104)$ \\
\hline \multirow[t]{2}{*}{ Noncognitive ability*born 1970-79 } & & & $0.273^{\star \star *}$ & & & 0.138 \\
\hline & & & $(0.063)$ & & & $(0.091)$ \\
\hline \multirow[t]{2}{*}{ Born 1950-59 } & $-0.340^{\star * *}$ & $-0.366^{\star * *}$ & $-0.382^{\star \star \star}$ & & & \\
\hline & $(0.106)$ & $(0.090)$ & $(0.091)$ & & & \\
\hline \multirow[t]{2}{*}{ Born 1970-79 } & $0.901^{\star \star \star}$ & $0.784^{\star \star \star}$ & $0.749^{\star \star \star}$ & & & \\
\hline & $(0.104)$ & $(0.090)$ & $(0.091)$ & & & \\
\hline R-squared & 0.326 & 0.323 & 0.337 & 0.002 & 0.028 & 0.033 \\
\hline F-test & $0.000^{\star \star \star}$ & 0.429 & 0.256 & 0.228 & 0.164 & 0.310 \\
\hline Twin-fixed effects & NO & NO & NO & YES & YES & YES \\
\hline Observations & \multicolumn{6}{|c|}{3,74} \\
\hline
\end{tabular}

Notes: Standard errors in parentheses. * indicates $10 \%$ significance, ${ }^{* *} 5 \%$ significance, and *** $1 \%$ significance. "F-test" is the p-value from an F-test based on the null hypothesis that all health variables have zero effect. 
Table A5.2: Health conditions and educational attainment with cohort specific effects. MZ twins only

\begin{tabular}{|c|c|c|c|c|c|c|}
\hline VARIABLES & A & $\mathrm{B}$ & C & $\mathrm{D}$ & $\mathrm{E}$ & $\mathrm{F}$ \\
\hline Mental*born 1950-59 & $\begin{array}{c}-1.127^{\star \star \star} \\
(0.222)\end{array}$ & $\begin{array}{c}-0.154 \\
(0.195)\end{array}$ & $\begin{array}{c}0.177 \\
(0.209)\end{array}$ & $\begin{array}{c}0.028 \\
(0.223)\end{array}$ & $\begin{array}{c}0.057 \\
(0.221)\end{array}$ & $\begin{array}{c}0.084 \\
(0.235)\end{array}$ \\
\hline Mental*born 1960-69 & $\begin{array}{l}-0.737 \\
(0.486)\end{array}$ & $\begin{array}{l}-0.116 \\
(0.413)\end{array}$ & $\begin{array}{c}0.266 \\
(0.417)\end{array}$ & $\begin{array}{l}-0.161 \\
(0.446)\end{array}$ & $\begin{array}{l}-0.200 \\
(0.441)\end{array}$ & $\begin{array}{l}-0.089 \\
(0.453)\end{array}$ \\
\hline Mental*born 1970-79 & $\begin{array}{c}-3.165^{\star \star \star} \\
(0.913)\end{array}$ & $\begin{array}{c}-2.402^{\star \star \star} \\
(0.778)\end{array}$ & $\begin{array}{c}-2.152^{\star \star \star} \\
(0.774)\end{array}$ & $\begin{array}{l}-0.459 \\
(0.841)\end{array}$ & $\begin{array}{l}-0.452 \\
(0.832)\end{array}$ & $\begin{array}{l}-0.342 \\
(0.833)\end{array}$ \\
\hline Circulatory*born 1950-59 & $\begin{array}{l}-0.052 \\
(0.329)\end{array}$ & $\begin{array}{c}0.216 \\
(0.279)\end{array}$ & $\begin{array}{c}0.248 \\
(0.277)\end{array}$ & $\begin{array}{c}0.223 \\
(0.264)\end{array}$ & $\begin{array}{c}0.286 \\
(0.262)\end{array}$ & $\begin{array}{c}0.298 \\
(0.263)\end{array}$ \\
\hline Circulatory*born 1960-69 & $\begin{array}{l}-0.100 \\
(0.403)\end{array}$ & $\begin{array}{c}0.074 \\
(0.341)\end{array}$ & $\begin{array}{c}0.113 \\
(0.339)\end{array}$ & $\begin{array}{l}-0.166 \\
(0.374)\end{array}$ & $\begin{array}{l}-0.143 \\
(0.370)\end{array}$ & $\begin{array}{l}-0.167 \\
(0.369)\end{array}$ \\
\hline Circulatory*born 1970-79 & $\begin{array}{l}-0.326 \\
(0.363)\end{array}$ & $\begin{array}{c}0.081 \\
(0.307)\end{array}$ & $\begin{array}{c}0.071 \\
(0.306)\end{array}$ & $\begin{array}{c}0.234 \\
(0.300)\end{array}$ & $\begin{array}{c}0.211 \\
(0.297)\end{array}$ & $\begin{array}{c}0.207 \\
(0.298)\end{array}$ \\
\hline Musculoskeletal*born 1950-59 & $\begin{array}{l}-0.031 \\
(0.198)\end{array}$ & $\begin{array}{l}-0.139 \\
(0.168)\end{array}$ & $\begin{array}{l}-0.093 \\
(0.167)\end{array}$ & $\begin{array}{c}0.540^{\star \star *} \\
(0.161)\end{array}$ & $\begin{array}{c}0.549 * * \star \\
(0.160)\end{array}$ & $\begin{array}{c}0.545^{\star \star \star} \\
(0.160)\end{array}$ \\
\hline Musculoskeletal*born 1960-69 & $\begin{array}{c}-0.548^{\star *} \\
(0.232)\end{array}$ & $\begin{array}{l}-0.254 \\
(0.197)\end{array}$ & $\begin{array}{l}-0.226 \\
(0.196)\end{array}$ & $\begin{array}{l}-0.264 \\
(0.188)\end{array}$ & $\begin{array}{l}-0.233 \\
(0.186)\end{array}$ & $\begin{array}{l}-0.255 \\
(0.186)\end{array}$ \\
\hline Musculoskeletal*born 1970-79 & $\begin{array}{l}-0.441^{\star *} \\
(0.176)\end{array}$ & $\begin{array}{l}-0.173 \\
(0.150)\end{array}$ & $\begin{array}{l}-0.108 \\
(0.149)\end{array}$ & $\begin{array}{l}-0.013 \\
(0.146)\end{array}$ & $\begin{array}{l}-0.002 \\
(0.144)\end{array}$ & $\begin{array}{c}0.015 \\
(0.144)\end{array}$ \\
\hline Digestive*born 1950-59 & $\begin{array}{l}-0.233 \\
(0.317)\end{array}$ & $\begin{array}{l}-0.317 \\
(0.269)\end{array}$ & $\begin{array}{l}-0.262 \\
(0.267)\end{array}$ & $\begin{array}{c}-0.522^{\star *} \\
(0.258)\end{array}$ & $\begin{array}{l}-0.472^{*} \\
(0.255)\end{array}$ & $\begin{array}{l}-0.468^{*} \\
(0.256)\end{array}$ \\
\hline Digestive*born 1960-69 & $\begin{array}{c}0.181 \\
(0.586)\end{array}$ & $\begin{array}{c}0.318 \\
(0.496)\end{array}$ & $\begin{array}{c}0.359 \\
(0.492)\end{array}$ & $\begin{array}{l}-1.021^{*} \\
(0.557)\end{array}$ & $\begin{array}{l}-1.053^{*} \\
(0.551)\end{array}$ & $\begin{array}{l}-0.989^{*} \\
(0.551)\end{array}$ \\
\hline Digestive*born 1970-79 & $\begin{array}{l}-0.267 \\
(0.331)\end{array}$ & $\begin{array}{c}0.072 \\
(0.281)\end{array}$ & $\begin{array}{c}0.165 \\
(0.280)\end{array}$ & $\begin{array}{c}0.159 \\
(0.275)\end{array}$ & $\begin{array}{c}0.156 \\
(0.272)\end{array}$ & $\begin{array}{c}0.163 \\
(0.273)\end{array}$ \\
\hline Skin*born 1950-59 & $\begin{array}{c}0.189 \\
(0.331)\end{array}$ & $\begin{array}{c}0.137 \\
(0.280)\end{array}$ & $\begin{array}{c}0.087 \\
(0.278)\end{array}$ & $\begin{array}{c}-0.841^{\star * *} \\
(0.308)\end{array}$ & $\begin{array}{c}-0.806^{\star * *} \\
(0.305)\end{array}$ & $\begin{array}{c}-0.805^{\star \star *} \\
(0.305)\end{array}$ \\
\hline Skin*born 1960-69 & $\begin{array}{c}0.166 \\
(0.321)\end{array}$ & $\begin{array}{l}0.521^{*} \\
(0.272)\end{array}$ & $\begin{array}{l}0.560^{\star \star} \\
(0.271)\end{array}$ & $\begin{array}{c}0.026 \\
(0.334)\end{array}$ & $\begin{array}{c}0.094 \\
(0.331)\end{array}$ & $\begin{array}{c}0.145 \\
(0.331)\end{array}$ \\
\hline Skin*born 1970-79 & $\begin{array}{l}-0.290 \\
(0.251)\end{array}$ & $\begin{array}{l}-0.003 \\
(0.213)\end{array}$ & $\begin{array}{c}0.066 \\
(0.212)\end{array}$ & $\begin{array}{l}-0.243 \\
(0.221)\end{array}$ & $\begin{array}{l}-0.178 \\
(0.219)\end{array}$ & $\begin{array}{l}-0.182 \\
(0.219)\end{array}$ \\
\hline Respiratory*born 1950-59 & $\begin{array}{l}0.521^{*} \\
(0.305)\end{array}$ & $\begin{array}{l}0.513^{\star \star} \\
(0.258)\end{array}$ & $\begin{array}{l}0.541^{\star *} \\
(0.256)\end{array}$ & $\begin{array}{c}0.459 \\
(0.302)\end{array}$ & $\begin{array}{l}0.495^{*} \\
(0.299)\end{array}$ & $\begin{array}{l}0.495^{\star} \\
(0.299)\end{array}$ \\
\hline Respiratory*born 1960-69 & $\begin{array}{c}0.289 \\
(0.245)\end{array}$ & $\begin{array}{c}0.116 \\
(0.208)\end{array}$ & $\begin{array}{c}0.093 \\
(0.206)\end{array}$ & $\begin{array}{l}-0.183 \\
(0.235)\end{array}$ & $\begin{array}{l}-0.184 \\
(0.232)\end{array}$ & $\begin{array}{l}-0.135 \\
(0.233)\end{array}$ \\
\hline Respiratory*born 1970-79 & $\begin{array}{l}0.351^{*} \\
(0.183)\end{array}$ & $\begin{array}{c}0.126 \\
(0.155)\end{array}$ & $\begin{array}{c}0.167 \\
(0.154)\end{array}$ & $\begin{array}{l}-0.133 \\
(0.173)\end{array}$ & $\begin{array}{l}-0.143 \\
(0.172)\end{array}$ & $\begin{array}{l}-0.122 \\
(0.172)\end{array}$ \\
\hline Injuries*born 1950-59 & $\begin{array}{l}-0.185 \\
(0.364)\end{array}$ & $\begin{array}{l}-0.294 \\
(0.308)\end{array}$ & $\begin{array}{l}-0.318 \\
(0.305)\end{array}$ & $\begin{array}{c}0.119 \\
(0.299)\end{array}$ & $\begin{array}{c}0.113 \\
(0.296)\end{array}$ & $\begin{array}{c}0.112 \\
(0.296)\end{array}$ \\
\hline Injuries*born 1960-69 & $\begin{array}{l}-0.092 \\
(0.368)\end{array}$ & $\begin{array}{c}0.087 \\
(0.312)\end{array}$ & $\begin{array}{c}0.129 \\
(0.310)\end{array}$ & $\begin{array}{l}-0.199 \\
(0.284)\end{array}$ & $\begin{array}{l}-0.182 \\
(0.282)\end{array}$ & $\begin{array}{l}-0.155 \\
(0.282)\end{array}$ \\
\hline Injuries*born 1970-79 & $\begin{array}{c}0.017 \\
(0.229)\end{array}$ & $\begin{array}{c}0.160 \\
(0.194)\end{array}$ & $\begin{array}{c}0.215 \\
(0.193)\end{array}$ & $\begin{array}{l}-0.018 \\
(0.179)\end{array}$ & $\begin{array}{l}-0.053 \\
(0.178)\end{array}$ & $\begin{array}{l}-0.029 \\
(0.178)\end{array}$ \\
\hline Cognitive ability*born 1950-59 & & $\begin{array}{c}1.361^{\star \star *} \\
(0.057)\end{array}$ & $\begin{array}{c}1.278^{* \star *} \\
(0.060)\end{array}$ & & $\begin{array}{c}0.347^{* * *} \\
(0.105)\end{array}$ & $\begin{array}{l}0.347^{\star \star \star} \\
(0.106)\end{array}$ \\
\hline Cognitive ability*born 1960-69 & & $\begin{array}{c}1.163^{\star \star \star} \\
(0.064)\end{array}$ & $\begin{array}{c}1.030 * * \star \\
(0.070)\end{array}$ & & $\begin{array}{c}0.529 * * * \\
(0.122)\end{array}$ & $\begin{array}{c}0.448^{\star \star \star} \\
(0.126)\end{array}$ \\
\hline Cognitive ability*born 1970-79 & & $\begin{array}{c}1.227^{\star \star \star} \\
(0.051)\end{array}$ & $\begin{array}{c}1.129 * * \star \\
(0.056)\end{array}$ & & $\begin{array}{c}0.395^{* * *} \\
(0.110)\end{array}$ & $\begin{array}{c}0.372^{\star \star \star} \\
(0.111)\end{array}$ \\
\hline Noncog. ability*born 1950-59 & & & $\begin{array}{c}0.257^{\star * *} \\
(0.062)\end{array}$ & & & $\begin{array}{c}0.011 \\
(0.083)\end{array}$ \\
\hline Noncog. ability*born 1960-69 & & & $0.360 * \star \star$ & & & $0.262^{\star \star}$ \\
\hline
\end{tabular}




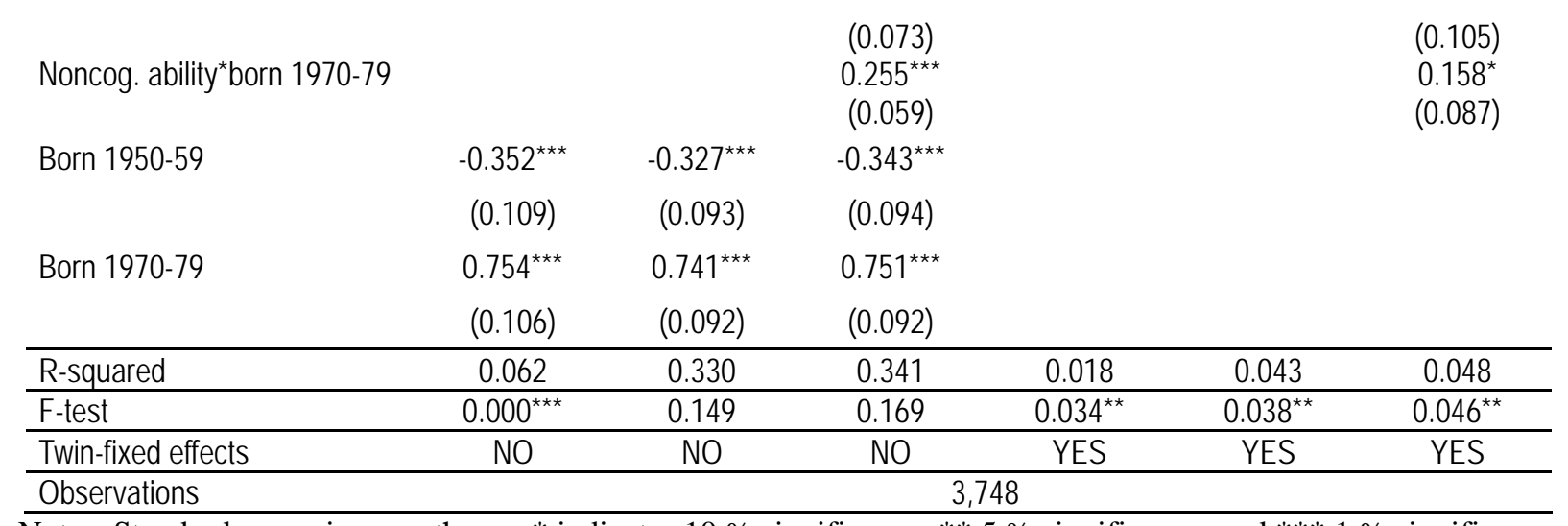

Notes: Standard errors in parentheses. * indicates $10 \%$ significance, ** $5 \%$ significance, and *** $1 \%$ significance. "F-test" is the p-value from an F-test based on the null hypothesis that all health variables have zero effect. 
Table A5.3: Physical test variables and educational attainment with cohort specific effects

\begin{tabular}{|c|c|c|c|c|c|c|}
\hline VARIABLES & A & $\mathrm{B}$ & $\mathrm{C}$ & $\mathrm{D}$ & $\mathrm{E}$ & $\mathrm{F}$ \\
\hline Low phys. cap.*born 1950-59 & $\begin{array}{c}-1.088^{\star \star \star} \\
(0.266)\end{array}$ & $\begin{array}{l}-0.401^{*} \\
(0.227)\end{array}$ & $\begin{array}{l}-0.240 \\
(0.229)\end{array}$ & $\begin{array}{l}-0.426 \\
(0.280)\end{array}$ & $\begin{array}{c}-0.409 \\
(0.277)\end{array}$ & $\begin{array}{l}-0.417 \\
(0.279)\end{array}$ \\
\hline Low phys. cap.*born 1960-69 & $\begin{array}{c}-0.896^{\star \star} \\
(0.380)\end{array}$ & $\begin{array}{l}-0.403 \\
(0.323)\end{array}$ & $\begin{array}{l}-0.187 \\
(0.324)\end{array}$ & $\begin{array}{c}0.323 \\
(0.367)\end{array}$ & $\begin{array}{c}0.389 \\
(0.364)\end{array}$ & $\begin{array}{c}0.442 \\
(0.366)\end{array}$ \\
\hline Low phys. cap.*born 1970-79 & $\begin{array}{l}-0.693^{*} \\
(0.370)\end{array}$ & $\begin{array}{l}-0.347 \\
(0.314)\end{array}$ & $\begin{array}{l}-0.070 \\
(0.316)\end{array}$ & $\begin{array}{c}0.281 \\
(0.310)\end{array}$ & $\begin{array}{c}0.386 \\
(0.309)\end{array}$ & $\begin{array}{c}0.381 \\
(0.309)\end{array}$ \\
\hline Weak handgrip*born 1950-59 & $\begin{array}{c}0.051 \\
(0.283)\end{array}$ & $\begin{array}{c}0.383 \\
(0.240)\end{array}$ & $\begin{array}{l}0.436^{*} \\
(0.239)\end{array}$ & $\begin{array}{c}0.240 \\
(0.262)\end{array}$ & $\begin{array}{c}0.219 \\
(0.260)\end{array}$ & $\begin{array}{c}0.226 \\
(0.262)\end{array}$ \\
\hline Weak handgrip*born 1960-69 & $\begin{array}{l}-0.047 \\
(0.390)\end{array}$ & $\begin{array}{c}0.479 \\
(0.332)\end{array}$ & $\begin{array}{l}0.612^{\star} \\
(0.331)\end{array}$ & $\begin{array}{l}-0.611 \\
(0.379)\end{array}$ & $\begin{array}{l}-0.443 \\
(0.378)\end{array}$ & $\begin{array}{l}-0.380 \\
(0.378)\end{array}$ \\
\hline Weak handgrip*born 1970-79 & $\begin{array}{c}0.512 \\
(0.352)\end{array}$ & $\begin{array}{l}0.647^{\star \star} \\
(0.299)\end{array}$ & $\begin{array}{l}0.698^{\star \star} \\
(0.297)\end{array}$ & $\begin{array}{c}0.038 \\
(0.313)\end{array}$ & $\begin{array}{c}0.084 \\
(0.310)\end{array}$ & $\begin{array}{c}0.090 \\
(0.310)\end{array}$ \\
\hline Hypertension*born 1950-59 & $\begin{array}{l}-0.104 \\
(0.156)\end{array}$ & $\begin{array}{l}-0.002 \\
(0.133)\end{array}$ & $\begin{array}{l}-0.013 \\
(0.132)\end{array}$ & $\begin{array}{c}0.161 \\
(0.142)\end{array}$ & $\begin{array}{c}0.147 \\
(0.141)\end{array}$ & $\begin{array}{c}0.147 \\
(0.141)\end{array}$ \\
\hline Hypertension*born 1960-69 & $\begin{array}{l}-0.063 \\
(0.180)\end{array}$ & $\begin{array}{c}0.021 \\
(0.152)\end{array}$ & $\begin{array}{c}0.044 \\
(0.152)\end{array}$ & $\begin{array}{c}0.187 \\
(0.164)\end{array}$ & $\begin{array}{c}0.207 \\
(0.162)\end{array}$ & $\begin{array}{c}0.236 \\
(0.162)\end{array}$ \\
\hline Hypertension*born 1970-79 & $\begin{array}{c}0.135 \\
(0.145)\end{array}$ & $\begin{array}{c}0.059 \\
(0.123)\end{array}$ & $\begin{array}{c}0.031 \\
(0.122)\end{array}$ & $\begin{array}{c}0.025 \\
(0.129)\end{array}$ & $\begin{array}{c}0.011 \\
(0.128)\end{array}$ & $\begin{array}{c}0.020 \\
(0.128)\end{array}$ \\
\hline Overweight*born 1950-59 & $\begin{array}{c}-1.071^{\star \star *} \\
(0.368)\end{array}$ & $\begin{array}{l}-0.556^{*} \\
(0.313)\end{array}$ & $\begin{array}{l}-0.597^{\star} \\
(0.310)\end{array}$ & $\begin{array}{c}0.270 \\
(0.328)\end{array}$ & $\begin{array}{c}0.288 \\
(0.325)\end{array}$ & $\begin{array}{c}0.289 \\
(0.325)\end{array}$ \\
\hline Overweight*born 1960-69 & $\begin{array}{c}-0.686^{\star *} \\
(0.308)\end{array}$ & $\begin{array}{l}-0.499^{*} \\
(0.261)\end{array}$ & $\begin{array}{l}-0.408 \\
(0.260)\end{array}$ & $\begin{array}{l}-0.554 \\
(0.387)\end{array}$ & $\begin{array}{l}-0.424 \\
(0.384)\end{array}$ & $\begin{array}{l}-0.385 \\
(0.384)\end{array}$ \\
\hline Overweight*born 1970-79 & $\begin{array}{c}-0.569^{\star *} \\
(0.241)\end{array}$ & $\begin{array}{l}-0.365^{*} \\
(0.204)\end{array}$ & $\begin{array}{l}-0.386^{\star} \\
(0.203)\end{array}$ & $\begin{array}{l}-0.059 \\
(0.257)\end{array}$ & $\begin{array}{l}-0.056 \\
(0.254)\end{array}$ & $\begin{array}{l}-0.030 \\
(0.254)\end{array}$ \\
\hline Short*born 1950-59 & $\begin{array}{c}-0.873^{\star \star \star} \\
(0.295)\end{array}$ & $\begin{array}{l}-0.320 \\
(0.251)\end{array}$ & $\begin{array}{l}-0.313 \\
(0.249)\end{array}$ & $\begin{array}{l}-0.654^{*} \\
(0.396)\end{array}$ & $\begin{array}{l}-0.616 \\
(0.393)\end{array}$ & $\begin{array}{l}-0.616 \\
(0.392)\end{array}$ \\
\hline Short*born 1960-69 & $\begin{array}{c}0.075 \\
(0.321)\end{array}$ & $\begin{array}{c}0.260 \\
(0.273)\end{array}$ & $\begin{array}{c}0.233 \\
(0.270)\end{array}$ & $\begin{array}{c}0.033 \\
(0.563)\end{array}$ & $\begin{array}{c}0.225 \\
(0.560)\end{array}$ & $\begin{array}{c}0.318 \\
(0.560)\end{array}$ \\
\hline Short*born 1970-79 & $\begin{array}{c}-0.788^{\star *} \\
(0.314)\end{array}$ & $\begin{array}{l}-0.307 \\
(0.267)\end{array}$ & $\begin{array}{c}-0.267 \\
(0.265)\end{array}$ & $\begin{array}{l}-0.284 \\
(0.451)\end{array}$ & $\begin{array}{l}-0.212 \\
(0.448)\end{array}$ & $\begin{array}{l}-0.181 \\
(0.448)\end{array}$ \\
\hline Low visual acc.*born 1950-59 & $\begin{array}{l}-0.167 \\
(0.264)\end{array}$ & $\begin{array}{c}0.127 \\
(0.224)\end{array}$ & $\begin{array}{c}0.148 \\
(0.223)\end{array}$ & $\begin{array}{c}0.176 \\
(0.251)\end{array}$ & $\begin{array}{c}0.242 \\
(0.249)\end{array}$ & $\begin{array}{c}0.247 \\
(0.250)\end{array}$ \\
\hline Low visual acc.*born 1960-69 & $\begin{array}{l}-0.438 \\
(0.310)\end{array}$ & $\begin{array}{l}-0.241 \\
(0.263)\end{array}$ & $\begin{array}{l}-0.189 \\
(0.262)\end{array}$ & $\begin{array}{l}-0.430 \\
(0.288)\end{array}$ & $\begin{array}{l}-0.317 \\
(0.287)\end{array}$ & $\begin{array}{l}-0.283 \\
(0.287)\end{array}$ \\
\hline Low visual acc.*born 1970-79 & $\begin{array}{l}-0.209 \\
(0.313)\end{array}$ & $\begin{array}{l}-0.013 \\
(0.265)\end{array}$ & $\begin{array}{c}0.018 \\
(0.264)\end{array}$ & $\begin{array}{l}-0.010 \\
(0.277)\end{array}$ & $\begin{array}{c}0.031 \\
(0.275)\end{array}$ & $\begin{array}{c}0.029 \\
(0.274)\end{array}$ \\
\hline Low hearing*born 1950-59 & $\begin{array}{l}-0.518^{\star *} \\
(0.244)\end{array}$ & $\begin{array}{l}-0.457^{\star *} \\
(0.207)\end{array}$ & $\begin{array}{l}-0.435^{* *} \\
(0.205)\end{array}$ & $\begin{array}{l}-0.290 \\
(0.220)\end{array}$ & $\begin{array}{l}-0.294 \\
(0.218)\end{array}$ & $\begin{array}{l}-0.293 \\
(0.218)\end{array}$ \\
\hline Low hearing*born 1960-69 & $\begin{array}{c}0.275 \\
(0.320)\end{array}$ & $\begin{array}{c}0.417 \\
(0.271)\end{array}$ & $\begin{array}{c}0.386 \\
(0.269)\end{array}$ & $\begin{array}{l}-0.087 \\
(0.265)\end{array}$ & $\begin{array}{l}-0.098 \\
(0.262)\end{array}$ & $\begin{array}{l}-0.175 \\
(0.263)\end{array}$ \\
\hline Low hearing*born 1970-79 & $\begin{array}{l}-0.518^{*} \\
(0.310)\end{array}$ & $\begin{array}{l}-0.044 \\
(0.263)\end{array}$ & $\begin{array}{c}0.060 \\
(0.263)\end{array}$ & $\begin{array}{c}0.139 \\
(0.258)\end{array}$ & $\begin{array}{c}0.151 \\
(0.256)\end{array}$ & $\begin{array}{c}0.150 \\
(0.256)\end{array}$ \\
\hline Cognitive ability*born 1950-59 & & $\begin{array}{c}1.345^{\star \star \star} \\
(0.057)\end{array}$ & $\begin{array}{c}1.258^{\star * *} \\
(0.060)\end{array}$ & & $\begin{array}{c}0.358^{\star \star \star} \\
(0.105)\end{array}$ & $\begin{array}{c}0.357^{\star \star \star} \\
(0.106)\end{array}$ \\
\hline Cognitive ability*born 1960-69 & & $\begin{array}{l}1.160^{* * *} \\
(0.064)\end{array}$ & $\begin{array}{c}1.038^{* \star *} \\
(0.070)\end{array}$ & & $\begin{array}{c}0.505^{\star \star \star} \\
(0.125)\end{array}$ & $\begin{array}{c}0.429 \star \star \star \\
(0.128)\end{array}$ \\
\hline Cognitive ability*born 1970-79 & & $\begin{array}{c}1.219^{* \star *} \\
(0.051)\end{array}$ & $\begin{array}{c}1.109 * * * \\
(0.056)\end{array}$ & & $\begin{array}{c}0.411^{\star \star \star} \\
(0.111)\end{array}$ & $\begin{array}{c}0.385^{\star \star \star} \\
(0.112)\end{array}$ \\
\hline Noncog. ability*born 1950-59 & & & $\begin{array}{c}0.235^{\star \star *} \\
(0.058)\end{array}$ & & & $\begin{array}{l}-0.001 \\
(0.080)\end{array}$ \\
\hline Noncog. ability*born 1960-69 & & & $0.338 * * *$ & & & $0.285^{\star \star \star}$ \\
\hline
\end{tabular}




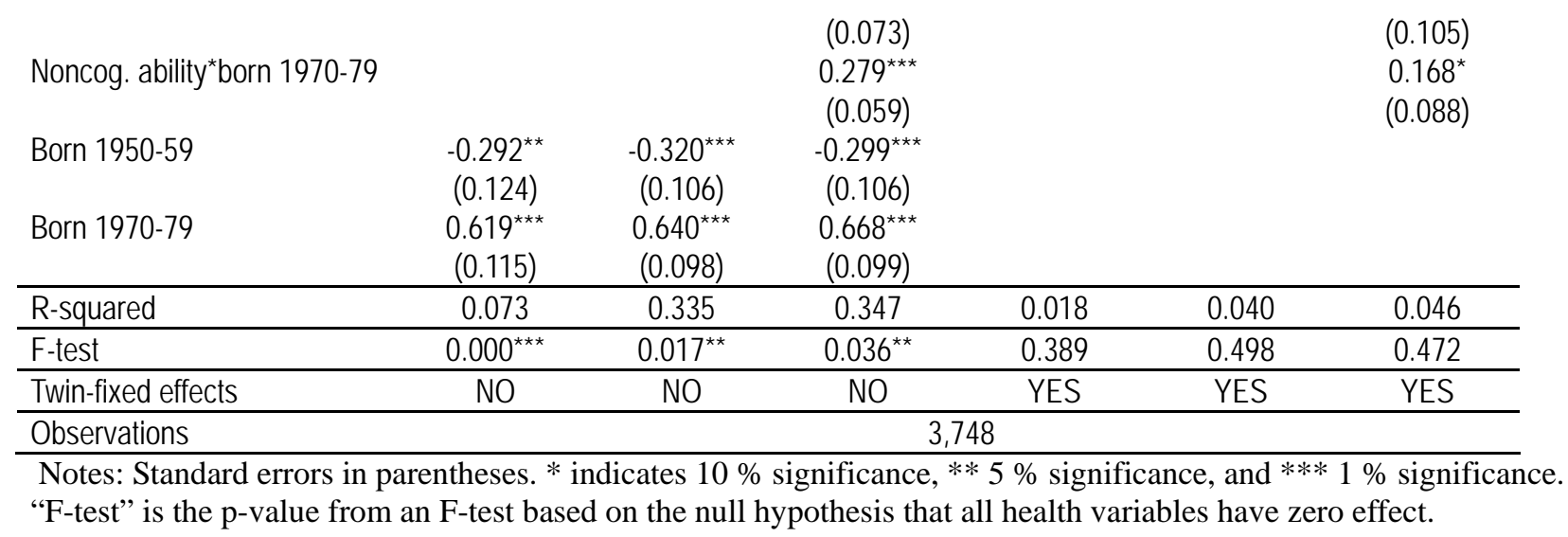


Table A5.4: Health conditions and educational attainment with cohort specific effects. Both MZ and DZ twins

\begin{tabular}{|c|c|c|c|c|c|c|}
\hline VARIABLES & $\mathrm{A}$ & $\mathrm{B}$ & $\mathrm{C}$ & $\mathrm{D}$ & $E$ & $\mathrm{~F}$ \\
\hline Mental*born 1950-59 & $\begin{array}{c}-1.029 * \star \star \\
(0.119)\end{array}$ & $\begin{array}{c}-0.106 \\
(0.105)\end{array}$ & $\begin{array}{c}0.184 \\
(0.112)\end{array}$ & $\begin{array}{l}-0.090 \\
(0.134)\end{array}$ & $\begin{array}{c}0.085 \\
(0.131)\end{array}$ & $\begin{array}{c}0.148 \\
(0.138)\end{array}$ \\
\hline Mental*born 1960-69 & $\begin{array}{c}-0.797^{\star \star \star} \\
(0.205)\end{array}$ & $\begin{array}{l}-0.097 \\
(0.176)\end{array}$ & $\begin{array}{c}0.287 \\
(0.179)\end{array}$ & $\begin{array}{l}-0.359 \\
(0.221)\end{array}$ & $\begin{array}{l}-0.142 \\
(0.215)\end{array}$ & $\begin{array}{l}-0.006 \\
(0.218)\end{array}$ \\
\hline Mental*born 1970-79 & $\begin{array}{c}-2.249 \star \star \star \\
(0.389)\end{array}$ & $\begin{array}{c}-1.507^{\star \star \star} \\
(0.332)\end{array}$ & $\begin{array}{c}-1.265^{\star \star \star} \\
(0.330)\end{array}$ & $\begin{array}{l}-0.105 \\
(0.457)\end{array}$ & $\begin{array}{l}-0.212 \\
(0.443)\end{array}$ & $\begin{array}{l}-0.151 \\
(0.443)\end{array}$ \\
\hline Circulatory*born 1950-59 & $\begin{array}{l}-0.179 \\
(0.219)\end{array}$ & $\begin{array}{l}-0.100 \\
(0.186)\end{array}$ & $\begin{array}{l}-0.060 \\
(0.184)\end{array}$ & $\begin{array}{l}-0.111 \\
(0.201)\end{array}$ & $\begin{array}{l}-0.066 \\
(0.195)\end{array}$ & $\begin{array}{l}-0.062 \\
(0.194)\end{array}$ \\
\hline Circulatory*born 1960-69 & $\begin{array}{l}-0.317 \\
(0.249)\end{array}$ & $\begin{array}{l}-0.079 \\
(0.211)\end{array}$ & $\begin{array}{l}-0.061 \\
(0.209)\end{array}$ & $\begin{array}{l}-0.370 \\
(0.245)\end{array}$ & $\begin{array}{l}-0.305 \\
(0.237)\end{array}$ & $\begin{array}{l}-0.333 \\
(0.237)\end{array}$ \\
\hline Circulatory*born 1970-79 & $\begin{array}{l}-0.014 \\
(0.236)\end{array}$ & $\begin{array}{l}0.342^{\star} \\
(0.200)\end{array}$ & $\begin{array}{c}0.293 \\
(0.198)\end{array}$ & $\begin{array}{c}0.215 \\
(0.233)\end{array}$ & $\begin{array}{c}0.289 \\
(0.225)\end{array}$ & $\begin{array}{c}0.285 \\
(0.225)\end{array}$ \\
\hline Musculoskeletal*born 1950-59 & $\begin{array}{l}-0.008 \\
(0.112)\end{array}$ & $\begin{array}{l}-0.058 \\
(0.095)\end{array}$ & $\begin{array}{l}-0.015 \\
(0.094)\end{array}$ & $\begin{array}{l}0.234^{\star *} \\
(0.108)\end{array}$ & $\begin{array}{l}0.250^{* *} \\
(0.104)\end{array}$ & $\begin{array}{l}0.264^{\star *} \\
(0.104)\end{array}$ \\
\hline Musculoskeletal*born 1960-69 & $\begin{array}{c}-0.561^{\star \star \star} \\
(0.143)\end{array}$ & $\begin{array}{l}-0.205^{\star} \\
(0.121)\end{array}$ & $\begin{array}{l}-0.159 \\
(0.120)\end{array}$ & $\begin{array}{l}-0.210 \\
(0.134)\end{array}$ & $\begin{array}{l}-0.093 \\
(0.131)\end{array}$ & $\begin{array}{l}-0.084 \\
(0.130)\end{array}$ \\
\hline Musculoskeletal*born 1970-79 & $\begin{array}{c}-0.484^{\star \star \star} \\
(0.108)\end{array}$ & $\begin{array}{c}-0.256^{\star \star \star} \\
(0.092)\end{array}$ & $\begin{array}{l}-0.173^{*} \\
(0.091)\end{array}$ & $\begin{array}{l}-0.092 \\
(0.104)\end{array}$ & $\begin{array}{l}-0.014 \\
(0.101)\end{array}$ & $\begin{array}{l}-0.000 \\
(0.101)\end{array}$ \\
\hline Digestive*born 1950-59 & $\begin{array}{c}-0.011 \\
(0.185)\end{array}$ & $\begin{array}{l}-0.054 \\
(0.157)\end{array}$ & $\begin{array}{c}0.003 \\
(0.155)\end{array}$ & $\begin{array}{l}-0.030 \\
(0.171)\end{array}$ & $\begin{array}{c}0.016 \\
(0.166)\end{array}$ & $\begin{array}{c}0.032 \\
(0.166)\end{array}$ \\
\hline Digestive*born 1960-69 & $\begin{array}{c}0.329 \\
(0.273)\end{array}$ & $\begin{array}{l}0.480^{* *} \\
(0.231)\end{array}$ & $\begin{array}{l}0.560^{\star *} \\
(0.229)\end{array}$ & $\begin{array}{c}0.187 \\
(0.257)\end{array}$ & $\begin{array}{c}0.306 \\
(0.249)\end{array}$ & $\begin{array}{c}0.330 \\
(0.248)\end{array}$ \\
\hline Digestive*born 1970-79 & $\begin{array}{l}-0.157 \\
(0.219)\end{array}$ & $\begin{array}{c}0.024 \\
(0.186)\end{array}$ & $\begin{array}{c}0.149 \\
(0.184)\end{array}$ & $\begin{array}{c}0.329 \\
(0.208)\end{array}$ & $\begin{array}{c}0.318 \\
(0.201)\end{array}$ & $\begin{array}{c}0.325 \\
(0.201)\end{array}$ \\
\hline Skin*born 1950-59 & $\begin{array}{l}0.339^{*} \\
(0.173)\end{array}$ & $\begin{array}{l}0.292^{\star \star} \\
(0.146)\end{array}$ & $\begin{array}{l}0.285^{\star *} \\
(0.145)\end{array}$ & $\begin{array}{c}0.109 \\
(0.168)\end{array}$ & $\begin{array}{c}0.077 \\
(0.163)\end{array}$ & $\begin{array}{c}0.080 \\
(0.163)\end{array}$ \\
\hline Skin*born 1960-69 & $\begin{array}{c}0.120 \\
(0.198)\end{array}$ & $\begin{array}{c}0.250 \\
(0.168)\end{array}$ & $\begin{array}{l}0.284^{*} \\
(0.166)\end{array}$ & $\begin{array}{c}0.120 \\
(0.210)\end{array}$ & $\begin{array}{c}0.143 \\
(0.204)\end{array}$ & $\begin{array}{c}0.141 \\
(0.203)\end{array}$ \\
\hline Skin*born 1970-79 & $\begin{array}{c}-0.068 \\
(0.164)\end{array}$ & $\begin{array}{c}0.005 \\
(0.139)\end{array}$ & $\begin{array}{c}0.053 \\
(0.138)\end{array}$ & $\begin{array}{l}-0.044 \\
(0.160)\end{array}$ & $\begin{array}{l}-0.077 \\
(0.156)\end{array}$ & $\begin{array}{l}-0.071 \\
(0.156)\end{array}$ \\
\hline Respiratory*born 1950-59 & $\begin{array}{c}0.281 \\
(0.188)\end{array}$ & $\begin{array}{c}0.144 \\
(0.159)\end{array}$ & $\begin{array}{c}0.183 \\
(0.157)\end{array}$ & $\begin{array}{l}-0.137 \\
(0.195)\end{array}$ & $\begin{array}{l}-0.146 \\
(0.189)\end{array}$ & $\begin{array}{l}-0.135 \\
(0.189)\end{array}$ \\
\hline Respiratory*born 1960-69 & $\begin{array}{l}0.354^{\star *} \\
(0.146)\end{array}$ & $\begin{array}{c}0.024 \\
(0.124)\end{array}$ & $\begin{array}{c}0.039 \\
(0.123)\end{array}$ & $\begin{array}{l}-0.120 \\
(0.154)\end{array}$ & $\begin{array}{l}-0.143 \\
(0.149)\end{array}$ & $\begin{array}{l}-0.117 \\
(0.149)\end{array}$ \\
\hline Respiratory*born 1970-79 & $\begin{array}{c}0.336^{\star \star \star} \\
(0.119)\end{array}$ & $\begin{array}{l}0.209 * * \\
(0.100)\end{array}$ & $\begin{array}{l}0.252^{\star *} \\
(0.100)\end{array}$ & $\begin{array}{c}0.006 \\
(0.124)\end{array}$ & $\begin{array}{c}0.020 \\
(0.120)\end{array}$ & $\begin{array}{c}0.028 \\
(0.120)\end{array}$ \\
\hline Injuries*born 1950-59 & $\begin{array}{c}-0.612^{\star \star \star} \\
(0.216)\end{array}$ & $\begin{array}{l}-0.321^{*} \\
(0.183)\end{array}$ & $\begin{array}{l}-0.300^{*} \\
(0.181)\end{array}$ & $\begin{array}{l}-0.202 \\
(0.200)\end{array}$ & $\begin{array}{l}-0.113 \\
(0.194)\end{array}$ & $\begin{array}{l}-0.101 \\
(0.194)\end{array}$ \\
\hline Injuries*born 1960-69 & $\begin{array}{l}-0.040 \\
(0.207)\end{array}$ & $\begin{array}{c}0.054 \\
(0.175)\end{array}$ & $\begin{array}{c}0.080 \\
(0.173)\end{array}$ & $\begin{array}{l}-0.009 \\
(0.198)\end{array}$ & $\begin{array}{c}0.032 \\
(0.191)\end{array}$ & $\begin{array}{c}0.045 \\
(0.191)\end{array}$ \\
\hline Injuries*born 1970-79 & $\begin{array}{c}-0.324^{* *} \\
(0.148)\end{array}$ & $\begin{array}{l}-0.149 \\
(0.126)\end{array}$ & $\begin{array}{l}-0.101 \\
(0.125)\end{array}$ & $\begin{array}{l}-0.120 \\
(0.138)\end{array}$ & $\begin{array}{l}-0.127 \\
(0.133)\end{array}$ & $\begin{array}{l}-0.111 \\
(0.133)\end{array}$ \\
\hline Cognitive ability*born 1950-59 & & $\begin{array}{c}1.252^{\star \star \star} \\
(0.033)\end{array}$ & $\begin{array}{c}1.168^{\star \star *} \\
(0.035)\end{array}$ & & $\begin{array}{c}0.607^{\star \star \star} \\
(0.054)\end{array}$ & $\begin{array}{c}0.577^{\star \star *} \\
(0.057)\end{array}$ \\
\hline Cognitive abilityborn 1960-69 & & $\begin{array}{c}1.182^{\star * \star} \\
(0.034)\end{array}$ & $\begin{array}{c}1.040^{\star * *} \\
(0.037)\end{array}$ & & $\begin{array}{c}0.633^{\star * *} \\
(0.061)\end{array}$ & $\begin{array}{c}0.572^{* * *} \\
(0.063)\end{array}$ \\
\hline Cognitive ability*born 1970-79 & & $\begin{array}{c}1.212 \star \star \star \\
(0.032)\end{array}$ & $\begin{array}{c}1.096^{\star \star *} \\
(0.034)\end{array}$ & & $\begin{array}{c}0.674^{\star \star \star} \\
(0.060)\end{array}$ & $\begin{array}{c}0.641^{\star * \star} \\
(0.062)\end{array}$ \\
\hline Noncog. ability*born 1950-59 & & & $\begin{array}{c}0.234^{\star \star *} \\
(0.035)\end{array}$ & & & $\begin{array}{l}0.082^{\star} \\
(0.048)\end{array}$ \\
\hline Noncog. ability*born 1960-69 & & & $0.399 * * *$ & & & $0.232^{\star * *}$ \\
\hline
\end{tabular}




\begin{tabular}{|c|c|c|c|c|c|c|}
\hline \multirow{3}{*}{ Noncog. ability*born 1970-79 } & \multicolumn{4}{|c|}{$(0.041)$} & & $(0.062)$ \\
\hline & \multicolumn{5}{|c|}{$0.314^{\star \star \star}$} & \multirow{6}{*}{$\begin{array}{l}0.126^{\star *} \\
(0.057)\end{array}$} \\
\hline & & & $(0.037)$ & & & \\
\hline \multirow[t]{2}{*}{ Born 1950-59 } & 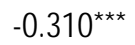 & $-0.371^{\star \star *}$ & $-0.361^{* * *}$ & & & \\
\hline & $(0.063)$ & $(0.054)$ & $(0.054)$ & & & \\
\hline \multirow[t]{2}{*}{ Born 1970-79 } & $0.724^{\star \star \star}$ & $0.732^{\star \star *}$ & $0.761 * * \star$ & & & \\
\hline & $(0.063)$ & $(0.054)$ & $(0.054)$ & & & \\
\hline R-squared & 0.058 & 0.327 & 0.340 & 0.004 & 0.068 & 0.073 \\
\hline F-test & $0.000 * \star \star$ & $0.000^{* \star \star}$ & $0.000 * * \star$ & 0.425 & 0.600 & 0.544 \\
\hline Twin-fixed effects & $\mathrm{NO}$ & $\mathrm{NO}$ & NO & YES & YES & YES \\
\hline Observations & \multicolumn{6}{|c|}{10,436} \\
\hline
\end{tabular}

Notes: Standard errors in parentheses. * indicates $10 \%$ significance, ** $5 \%$ significance, and *** $1 \%$ significance. "F-test" is the p-value from an F-test based on the null hypothesis that all health variables have zero effect. 